\title{
Therapy Approaches for Stargardt Disease
}

\author{
Elena Piotter ${ }^{1,2,+}$, Michelle E McClements ${ }^{1,2,+}$ and Robert E MacLaren ${ }^{1,2, *}$ \\ 1 Nuffield Laboratory of Ophthalmology, Department of Clinical Neurosciences, University of Oxford, \\ Oxford OX3 9DU, UK; enquiries@eye.ox.ac.uk \\ 2 Oxford University Hospitals NHS Foundation Trust NIHR Biomedical Research Centre, Oxford OX3 9DU, UK \\ * Correspondence: maclaren@eye.ox.ac.uk \\ + Authors contributed equally.
}

\section{check for}

updates

Citation: Piotter, E.; McClements, M.E.; MacLaren, R.E. Therapy Approaches for Stargardt Disease. Biomolecules 2021, 11, 1179. https:// doi.org/10.3390/biom11081179

Academic Editor: Eric B. Kmiec

Received: 24 June 2021

Accepted: 5 August 2021

Published: 9 August 2021

Publisher's Note: MDPI stays neutral with regard to jurisdictional claims in published maps and institutional affiliations.

Copyright: (c) 2021 by the authors. Licensee MDPI, Basel, Switzerland. This article is an open access article distributed under the terms and conditions of the Creative Commons Attribution (CC BY) license (https:/ / creativecommons.org/licenses/by/ $4.0 /)$.

\begin{abstract}
Despite being the most prevalent cause of inherited blindness in children, Stargardt disease is yet to achieve the same clinical trial success as has been achieved for other inherited retinal diseases. With an early age of onset and continual progression of disease over the life course of an individual, Stargardt disease appears to lend itself to therapeutic intervention. However, the aetiology provides issues not encountered with the likes of choroideremia and X-linked retinitis pigmentosa and this has led to a spectrum of treatment strategies that approach the problem from different aspects. These include therapeutics ranging from small molecules and anti-sense oligonucleotides to viral gene supplementation and cell replacement. The advancing development of CRISPR-based molecular tools is also likely to contribute to future therapies by way of genome editing. In this we review, we consider the most recent pre-clinical and clinical trial data relating to the different strategies being applied to the problem of generating a treatment for the large cohort of Stargardt disease patients worldwide.
\end{abstract}

Keywords: Stargardt disease; gene therapy; inherited retinal disease; CRISPR

\section{Introduction}

Stargardt disease is an inherited macular degeneration that typically presents in the first two decades of life [1]. The prevalence is in the region of 1 in 8-10,000 individuals. A recent British Ophthalmological Surveillance Unit (BOSU) study reported an annual incidence of 0.127 per 100,000; however, this postal-based questionnaire has a notoriously low reply rate from clinicians, due to the administrative burden resulting from identifying positive cases [2]. Stargardt disease patients typically make up a large proportion of patient cohorts within genetic clinics of eye disease [3,4]. The age of onset and rate of progression vary greatly, with most experiencing symptoms in their teens or earlier, and virtually all becoming severely visually impaired or legally blind by their 4th to 7th decade of life [1]. Given the relatively slow disease progression, there is a reasonable window for treatment intervention and an opportunity to improve or delay further degeneration throughout the lifetime of an individual. A diagnosis of Stargardt disease includes varying phenotypic and genotypic forms, of which STGD1 is the most common. This an autosomal recessive condition caused by mutations in the gene ABCA4, which encodes the ATP binding cassette protein family member 4 . In rare cases, Stargardt-like disease arises that often falls under the umbrella term of Stargardt disease. Stargardt-like disease is caused by autosomal dominant mutations in ELOVL4 (STGD3) or PROM1 (STGD4), which encode elongation of very-long-chain fatty acids and prominin 1, respectively. Note that the term STGD2 was discontinued in 2005, when it was discovered to be the same gene as STGD3 (https:/ / www.ncbi.nlm.nih.gov/gene/6784, accessed on 30 June 2021).

\section{1. $S T G D 1-A B C A 4$}

The ABCA4 protein is a transport protein essential to the visual cycle and is located specifically in the outer segments of photoreceptor cells (Figure 1). It is responsible 
for moving retinoids, in particular $N$-retinylidene-phosphatidylethanolamine and phosphatidylethanolamine, via a flippase mechanism from the lumen to the cytoplasmic side of the disc membranes. This process removes retinoids from the photoreceptor discs and in so doing enables continuation of the visual cycle $[5,6]$. When this process is disrupted due to non-functional $\mathrm{ABCA4}$, there is a build-up of retinoids in the disc membrane that leads to the formation of bis-retinoid fusion products, such as $\mathrm{N}$-retinylidene- $\mathrm{N}$ retinlyethanolamine (A2E) [7]. Photoreceptor cells constantly produce new disc membranes and as each new disc is formed, the older ones become more distal. The outer segments of photoreceptor cells are in contact with the supporting retinal pigment epithelium (RPE), one role of which is to phagocytose the distal discs. In a patient with STGD1 disease, the RPE cells consume the retinoid derivatives and as A2E is insoluble, it persists in these cells, where it has a tendency to aggregate and form lipofuscin [8]. This ultimately leads to cell damage and degeneration of the RPE cells and when the RPE cells die, the photoreceptor cells they support begin to lose function and also degenerate. In earlier stages of disease, the accumulation of bisretinoids throughout the cone cytoplasm may explain the early occult macular dystrophy phenotype that precedes cone dystrophy, long before RPE changes [9]. This review will focus on current and prospective treatments for STGD1, with further details on the function of ABCA4 to be found elsewhere [10]. Although mutations in ABCA4 had been proposed as risk factors for age-related macular degeneration (AMD) a decade ago [11], more recent extensive phenotype-genotype studies have defined late onset Stargardt disease as a distinct entity that appears clinically similar to AMD [12]. Hence, therapeutic interventions for ABCA4-related disease are unlikely to benefit a patient cohort beyond those with STGD1.

A

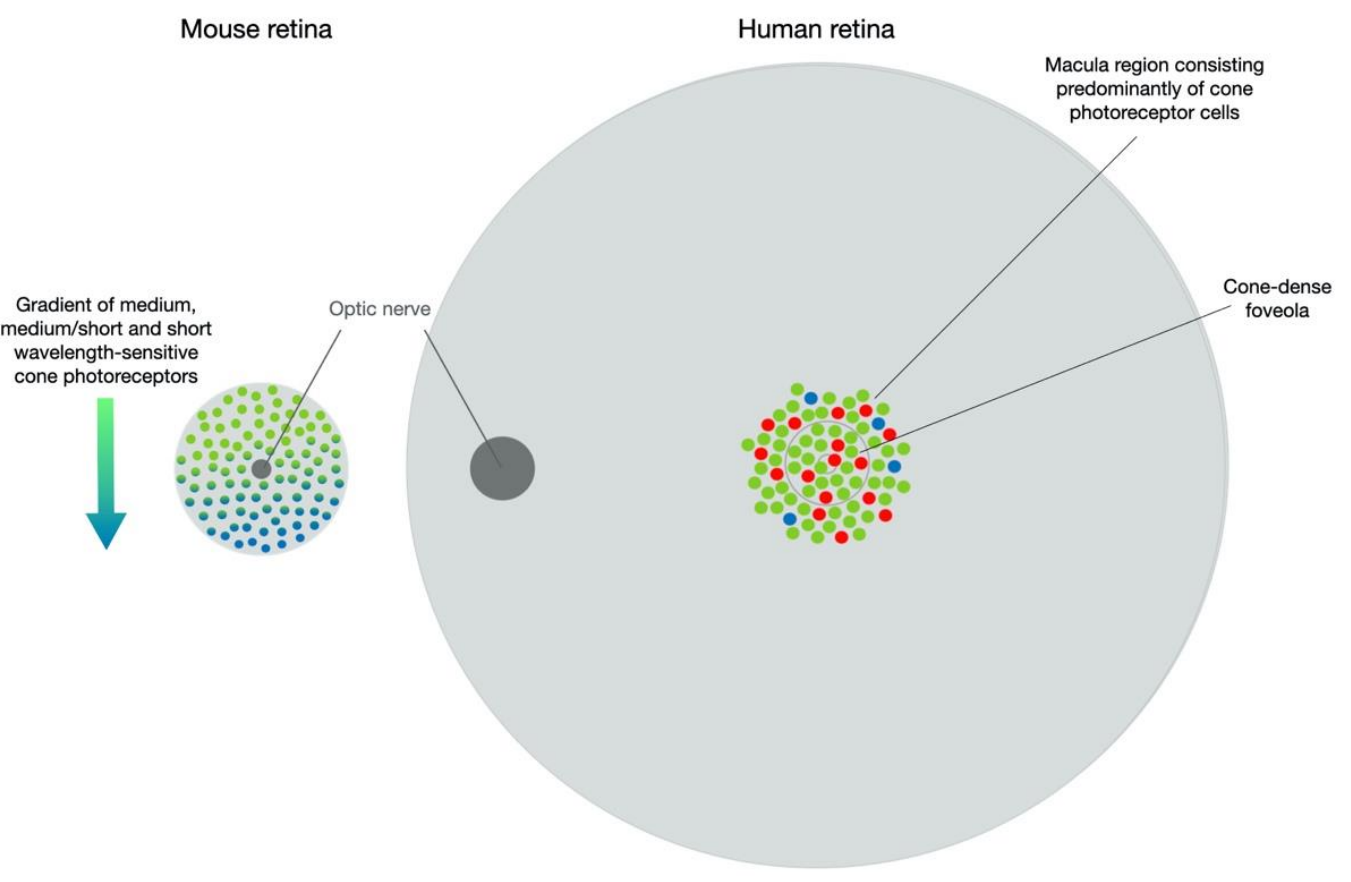

Figure 1. Cont. 


\section{B}

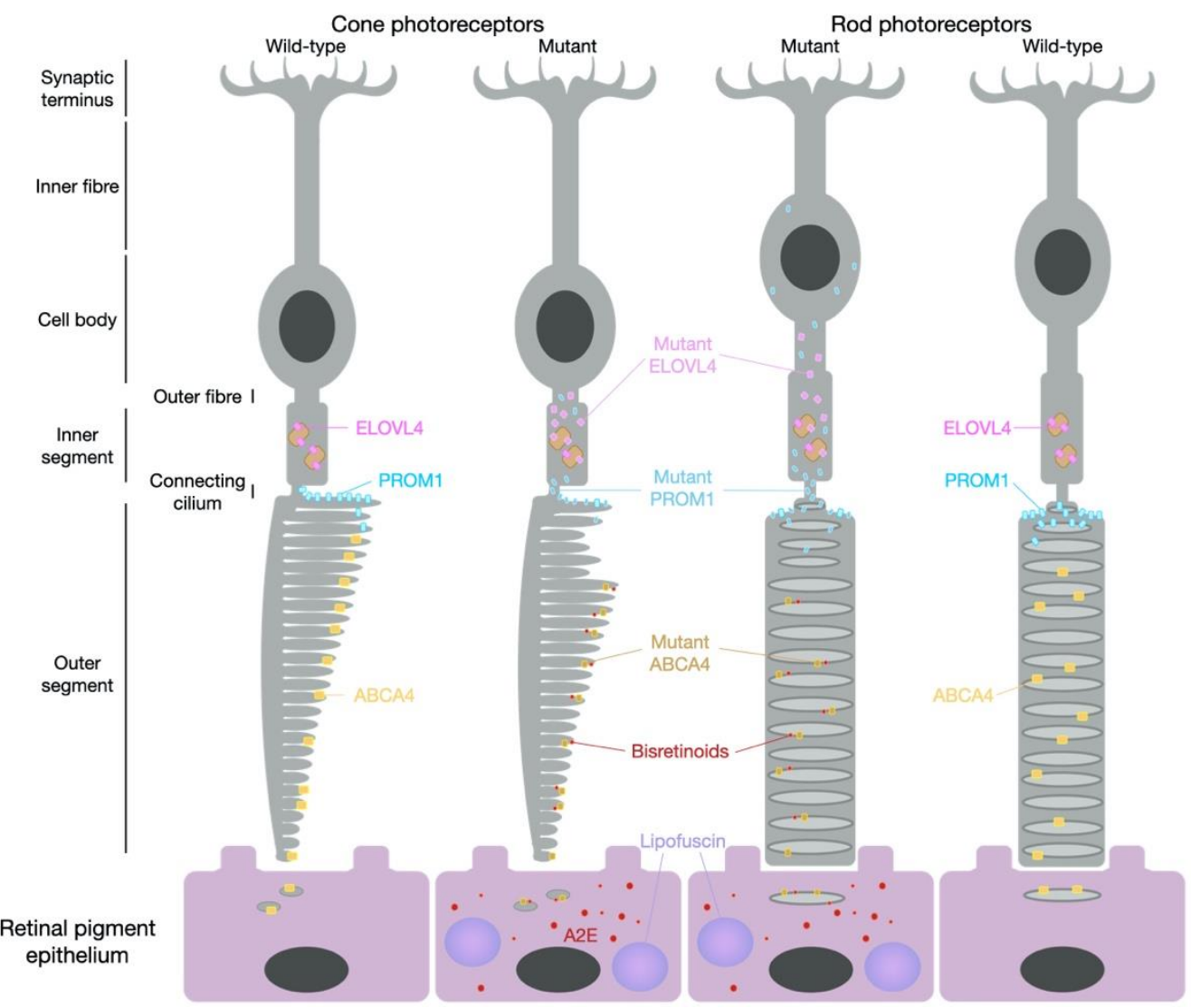

Figure 1. Comparisons of the human and mouse cone photoreceptor distribution and localisations of ABCA4, ELOVL4 and PROM1. (A) Rod photoreceptors comprise the majority of light-sensitive cells of the mouse retina with cone photoreceptors occurring in a decreasing gradient of medium-wavelength, medium/short-wavelength and short-wavelength sensitive varieties in a dorsal to ventral direction. By comparison, the human retina contains a macula region in which the foveola provides the site of maximum visual acuity and is densely packed with long- and medium-wavelength sensitive cone photoreceptors with short-wavelength sensitive cone photoreceptors occurring sporadically amongst the cones in the fovea centralis of the macula. Stargardt disease is characterised by a loss of cells in the cone-rich macula region. (B) In a wild-type state, ELOVL4 is located in the endoplasmic reticulum of photoreceptor cells, with mutant forms becoming mislocalised as well as losing function. PROM1 is typically located at the base of the outer segments where new discs are formed, and mutant PROM1 mislocalises within the photoreceptor cells and disc morphogenesis occurs. ABCA4 is present on the disc membranes and in mutant form causes dysregulation of the visual cycle, causing build-up of unwanted compounds in the disc membranes. When consumed by the RPE, these toxic compounds lead to lipofuscin accumulation and ultimately death of the RPE. ABCA4 = ATP-binding cassette transporter protein 4; ELOVL4 = elongation of very-long-chain fatty acids; PROM1 = prominin $1 ; \mathrm{RPE}=$ retinal pigment epithelium.

\subsection{STGD3-ELOVL4 (Allelic to the Former STGD2)}

ELVOL4 is also a membrane protein but is located in the endoplasmic reticulum and is involved in the biosynthesis of fatty acids [13]; in the retina expression appears to be limited to the photoreceptor cells [14]. Mutations in ELOVL4 not only lead to mislocalisation of ELOVL4, which has a negative impact on photoreceptor function [13], but also absence of enzymatic activity [15]. Photoreceptor outer segments containing mutant ELOVL4 protein also lead to phagolysosomal defects in the RPE, which further adds to the mechanism of disease [16]. Whilst autosomal dominant mutations in ELOVL4 cause STGD3, autosomal recessive mutations result in other conditions, including neuro-ichthyotic disease [17]. 


\subsection{STGD4-PROM1}

The PROM1 gene, also known as CD133, has at least five alternative promoters that provide tissue-dependent expression [18] and is a membrane glycoprotein most commonly known for being a stem cell marker [19]. In the retina, the prominin 1 protein is typically found at the base of the outer segments, where it makes important associations with other components critical to disc morphogenesis [20]. It has also been shown that PROM1 regulates autophagy in the RPE, a process that protects the RPE from lipofuscin accumulation [21]. Autosomal recessive mutations cause retinitis pigmentosa [22,23], which is characterised by peripheral loss of vision, whereas autosomal dominant mutations cause STGD4 and other forms of macular dystrophy $[23,24]$.

\section{Models of Stargardt Disease}

\subsection{Mouse Models}

A general issue when attempting to study diseases of the macula and assess the safety and efficacy of treatments, is that the favoured in vivo model, mice, have no macula. The murine retina is composed of $\sim 95 \%$ rod photoreceptors with a decreasing cone photoreceptor gradient occurring from the superior to inferior retina (Figure 1). By contrast, the macula region in humans is cone-dense with the retina outside of this region composed predominantly of rod photoreceptors. Whilst many naturally occurring and transgenic mouse models reliably mimic human inherited retinal diseases, mutations in genes that cause macular degenerations regularly fail to generate desired phenotypes.

For STGD1, the Abca4 knockout (KO) model has a complete absence of Abca4 protein. On an albino background carrying the homozygous Rpe65 Leu450Met mutation, the Abca4 $\mathrm{KO}$ presents loss of photoreceptor cells with increasing age (by 11 months) [25]. However, on a pigmented background this does not occur [26] yet both Abca4 $\mathrm{KO}$ models suffer from lipofuscin accumulation over time, which can be detected by the non-invasive technique of scanning laser ophthalmoscopy (SLO) and by direct quantification from post-mortem tissue by high-performance liquid chromatography (HPLC) analysis $[27,28]$. For SLO measurements, the $488 \mathrm{~nm}$ wavelength is considered to correlate to levels of $\mathrm{A} 2 \mathrm{E}$ and the $790 \mathrm{~nm}$ wavelength to lipofuscin [28]. To better reflect a human genotype, a STGD1 mouse model was created carrying Abca4 Leu541Pro and Ala1038Val (PV) mutations [29]. The expressed double-mutant was shown to generate Abca4 protein at reduced levels compared to wild-type mice. As with the $A b c a 4 \mathrm{KO}$ model, only age-related changes in structure were observed and there was comparable accumulation of $\mathrm{A} 2 \mathrm{E}$ and lipofuscin over time. Similarly, a homozygous Abca4 Asn965Ser model also presented with reduced levels of Abca4 protein in the photoreceptor cells with mislocalisation evident in the inner segment structures [30]. Consistent with other STGD1 mouse models, A2E and lipofuscin accumulation occurred with age, evident by SLO fluorescence assessments and HPLC quantification. Whilst there tends to be a general absence of gross structural and functional changes in mouse models of STGD1, the accumulation of A2E and lipofuscin do enable measurements of treatment efficacy by the reduction in these compounds post-treatment.

Due to the roles of Elovl4 in cell types other than the retina, homozygous Elovl4 KO mice do not survive beyond birth [31]. Heterozygous Elovl4 KOs develop normally with minimal structural or functional changes to the retina. The authors suggested that absence of the degenerative phenotype indicated that haploinsufficiency was not the mechanism for STGD3 disease. However, as previously mentioned, given the consistent problem in mimicking a macular disease in a mouse model, this was not fully supported until investigations into the retinal phenotype in the homozygous Elovl4 KOs determined normal retinal development prior to death [32]. Further evidence ruling out Elovl4 haploinsufficiency as the cause of STGD3 retinal degeneration came when transgenic and knock-in models were generated expressing disease-associated mutations [33-35]. Compared to previous models, these variants recapitulated human disease surprisingly well and exhibited loss of photoreceptor cells, abnormal function when measured by electroretinogram (ERG) and lipofuscin deposits in the RPE [36]. 
For investigations into disease pathology and treatment options for STGD4, there is a naturally occurring rd19 mouse model (http:/ /www.informatics.jax.org/allele/MGI: 5605699, accessed on 30 June 2021) in addition to transgenic [20] and Prom1 KO [37] models. The naturally occurring rd19 model carries a premature stop codon (Lys269X) and exhibits photoreceptor loss by 2 months of age with associated abnormal rod ERG responses. Similarly, the homozygous Prom 1 null mouse also showed photoreceptor degeneration and is highly sensitive to light with rearing of the mice under dark conditions able to significantly preserve retinal structure and function [37]. For investigations of human relevant mutations, human PROM1 knock-in mice were generated carrying the common Arg373Cys mutation, expressed specifically in rod photoreceptor cells [20]. In comparison to equivalent knock-in mice carrying the wild-type human sequence, mutant PROM1 expression caused mislocalisation of the protein and abnormal outer segment morphologies prior to degeneration.

\subsection{In Vitro Models}

Mouse models of disease provide an opportunity to investigate disease pathogenicity and treatment intervention, but the differences in phenotype can limit the usefulness of such models and there is therefore scope to expand pre-clinical testing to other models. Immortalised cell lines are commonly used to overexpress mutant protein forms and explore function. It is important to understand the expression profile, cellular localisation and function of a given mutant form in comparison to the wild-type variant in order to accurately evaluate the benefits of a subsequent treatment. Retinal genes are not often expressed natively in standard cell lines; therefore, exogenous DNA delivery is required. In addition to understanding the expression and localisation of mutant protein forms, information on the influence of a given mutation on function can also be achieved. In the case of ABCA4, this can be by way of ATPase activity [38] or for ELOVL4, the biosynthesis of very-long-chain fatty acids [15]. However, such in vitro experiments have their limitations. For example, assessing the impact of splice site mutations is challenging when using exogenous DNA delivery and can rely on midigenes (bacterially encoded splice intervals) that do not fully represent the final expression product [39]. If an in vitro system cannot reliably produce the mutated version of a protein for assessment of localisation, structure and function, evaluating subsequent therapy of the mutant to redeem the wild-type features could be limited. This has led to investigators exploring alternative models for in vitro assessments.

The generation of induced pluripotent stem cell (iPSC)-derived photoreceptor cells would be of great use to STGD1, STGD3 and STGD4 studies but this can be relatively technical [40]. Generating iPSCs can take 20-30 days, with the subsequent differentiation into retinal photoreceptor-like cells requiring a further 10-14 days of specialised culture conditions. As an alternative to this, a recent study presented evidence of $A B C A 4$ expression in cells isolated from human skin cells and hair follicles [41]. Comparison of hair follicles from control samples to those from a STGD1 patient carrying the mutation c.5836+2T $>\mathrm{G}$ revealed significantly lower $A B C A 4$ expression levels in the patient hair follicles. If hair follicles can be reliably used for assessment of $A B C A 4$ expression, then such samples might prove particularly useful in future testing of CRISPR-based mutation correction therapies (discussed later).

A further investment that would prove beneficial to the study of disease and treatment options for STGD1, STGD3 and STGD4 is the generation of retinal organoids from patient samples. After first generating iPSCs, differentiation into retinal organoids (an additional timeframe of 120-280 days depending on the degree of maturation desired) can provide evidence of disease phenotype, as has been seen with other such models for inherited retinal disease [42-49], and then provide an opportunity for correction of phenotype following treatment $[42,45,48]$.

Whilst there is no single ideal model for assessing the treatment potential of therapeutic interventions for Stargardt disease, a combination of testing in the models discussed (Table 1) would prove highly informative. Model selection will depend both on the genetic 
origin and the treatment strategy being applied and whilst there is currently no approved treatment for Stargardt disease, there are numerous candidates showing potential. Given the relative prevalence of STGD1, the majority of treatment options discussed in this review will relate to ABCA4-related strategies, but STGD3 and STGD4 options will be considered where appropriate.

Table 1. Summary of experimental models relevant for pre-clinical studies of Stargardt disease therapies. A2E $=N$-retinylidene$\mathrm{N}$-retinylethanolamine; $\mathrm{ABCA} 4=\mathrm{ATP}$-binding cassette transporter protein 4; ELOVL4 = elongation of very-long-chain fatty acids 4; $\mathrm{ERG}=$ electroretinogram; $\mathrm{KO}=$ knockout; $\mathrm{ONL}=$ outer nuclear layer; $\mathrm{PROM} 1=$ prominin $1 ; \mathrm{Rd} 19$ = retinal degeneration model 19; RPE = retinal pigment epithelium.

\begin{tabular}{|c|c|c|c|c|}
\hline Model Type & Details & Structural Features & Functional Features & Strengths/Limitations \\
\hline \multicolumn{5}{|l|}{ Mouse } \\
\hline STGD1 & Abca4 KO $[25,26]$ & $\begin{array}{l}\text { Absence of Abca } 4 \\
\text { expression. On an albino } \\
\text { background, loss of outer } \\
\text { nuclear layer (ONL) } \\
\text { structure at } 11 \text { months. } \\
\text { Pigmented mice show no } \\
\text { loss in structure. Lipofuscin } \\
\text { granule accumulation in the } \\
\text { RPE. }\end{array}$ & $\begin{array}{l}\text { Abca4 KO models exhibit } \\
\text { increased autofluorescence } \\
\text { compared to age-matched } \\
\text { wild-type mice that } \\
\text { correlates to accumulation } \\
\text { of bis- } \\
\text { retinoids/A2E/lipofuscin. }\end{array}$ & $\begin{array}{l}\text { Easy detection of ABCA4 } \\
\text { protein following gene } \\
\text { supplementation. Assessment } \\
\text { of pharmaceutical, dietary and } \\
\text { gene therapy efficacy } \\
\text { achievable by reduction in } \\
\text { autofluorescence and } \\
\text { associated build-up of } \\
\text { bisretinoids / A2E/lipofuscin. } \\
\text { However, the KO genotype } \\
\text { and absence of Abca4 does not } \\
\text { reflect typical human disease. }\end{array}$ \\
\hline$\overline{\mathrm{STG}} \overline{\mathrm{D}} \overline{1}^{----}$ & $\begin{array}{l}\text { Leu451Pro and } \\
\text { Ala1038Val (PV/PV) [29] } \\
\text { Asn965Ser [30] }\end{array}$ & $\begin{array}{l}\text { Reduced expression of } \\
\text { Abca4 with mislocalisation } \\
\text { within the photoreceptor } \\
\text { cells. }\end{array}$ & $\begin{array}{l}\text { Models exhibit increased } \\
\text { autofluorescence } \\
\text { compared to age-matched } \\
\text { wild-type mice that } \\
\text { correlates to accumulation } \\
\text { of bis- } \\
\text { retinoids/A2E/lipofuscin. }\end{array}$ & $\begin{array}{l}\text { Efficacy evident in these } \\
\text { models would be more } \\
\text { relevant to human disease and } \\
\text { achieved by rescue of } \\
\text { bisretinoid/A2E/lipofuscin } \\
\text { build-up and the associated } \\
\text { autofluorescence phenotype. }\end{array}$ \\
\hline$\overline{\text { STGD }}{ }^{-}$ & Elovi $\overline{\mathrm{KO}}[\overline{31}, \overline{32}]$ & Normal retinal structure. & Normal retinal function. & $\begin{array}{l}\text { The KO is of limited value as it } \\
\text { can only be reared as a } \\
\text { heterozygous model and offers } \\
\text { no clear features of retinal } \\
\text { disease. }\end{array}$ \\
\hline$\overline{\mathrm{STG}} \overline{\mathrm{D}}{ }^{-}-\cdots$ & $\begin{array}{l}\text { ELOVL } 4 \text { 5-bp deletion } \\
\text { knock-in [33-36] }\end{array}$ & $\begin{array}{l}----\overline{\text { Accumulation of ELOVL }} \overline{4} \text { at } \\
4 \text { months with progressive } \\
\text { loss of ONL and, in } \\
\text { particular, cones at } 6-18 \\
\text { months. }\end{array}$ & $\begin{array}{l}\text { Abnormal ERG and } \\
\text { accumulation of } \\
\text { lipofuscin. }\end{array}$ & $\begin{array}{l}\text { Rescue of retinal structure and } \\
\text { function. Transgenic models } \\
\text { are more representative of } \\
\text { human disease both in } \\
\text { genotype and phenotype. }\end{array}$ \\
\hline$\overline{\mathrm{STG}} \overline{\mathrm{D}} 4$ & $R \bar{d} 1 \overline{9}$ & $\begin{array}{l}\text { Progressive loss of ONL } \\
\text { beginning at } 2 \text { months of } \\
\text { age. }\end{array}$ & $\begin{array}{l}\text { Normal cone ERG but } \\
\text { abnormal rod a-wave } \\
\text { responses. }\end{array}$ & $\begin{array}{l}\text { This naturally occurring } \\
\text { model has yet to be used in } \\
\text { pre-clinical studies. }\end{array}$ \\
\hline$\overline{\text { STGD }} 4 \overline{-}$ & Prom1 KO $\overline{[37]}$ & $\begin{array}{l}\text { Extensive loss of } \mathrm{ONL} \\
\text { beginning at } 2 \text { weeks of age. }\end{array}$ & Abnormal ERG. & $\begin{array}{l}\text { Loss of retinal structure and } \\
\text { function begins early; } \\
\text { therefore, treatment } \\
\text { intervention may not be } \\
\text { provided in time to observe } \\
\text { efficacy. Rearing in the dark } \\
\text { could be applied to slow the } \\
\text { rate of degeneration. }\end{array}$ \\
\hline$\overline{\mathrm{STG}} \overline{\mathrm{C}} 4^{-}$ & $\begin{array}{l}P R O M 1 \text { Arg373Сys } \\
\text { knock-in [20] }\end{array}$ & $\begin{array}{l}\text { Mislocalisation of } \\
\text { PROM1with abnormal outer } \\
\text { segment morphology and } \\
\text { degeneration. }\end{array}$ & $\begin{array}{l}\text { Abnormal rod and cone } \\
\text { ERG by } 3 \text { months of age. }\end{array}$ & $\begin{array}{l}\text { The knock-in better reflects the } \\
\text { human state and offers an } \\
\text { opportunity to assess } \\
\text { treatment efficacy through } \\
\text { correction of structural and } \\
\text { functional changes. }\end{array}$ \\
\hline
\end{tabular}


Table 1. Cont.

\begin{tabular}{|c|c|c|c|c|}
\hline Model Type & Details & Structural Features & Functional Features & Strengths/Limitations \\
\hline \multicolumn{5}{|l|}{ In Vitro } \\
\hline Immortalised cell lines & Wild-type & $\begin{array}{l}\text { Lack of native retinal gene } \\
\text { expression and absence of } \\
\text { specialised retinal } \\
\text { structures. }\end{array}$ & $\begin{array}{l}\text { Enables expression and } \\
\text { localisation assessments } \\
\text { plus downstream isolation } \\
\text { and functional assays. }\end{array}$ & $\begin{array}{l}\text { Exogenous delivery of retinal } \\
\text { genes of interest is required } \\
\text { but basic assessments of } \\
\text { vectors and downstream } \\
\text { functional assays are } \\
\text { achievable. }\end{array}$ \\
\hline 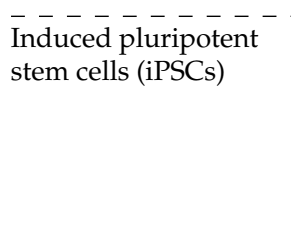 & $\begin{array}{l}-\overline{\text { Patient-specific }} \\
\text { genotype }\end{array}$ & $\begin{array}{l}\text { Cells can be differentiated to } \\
\text { better reflect photoreceptor } \\
\text { cell morphology and gene } \\
\text { expression profiles. }\end{array}$ & $\begin{array}{l}\text { Functional outputs could } \\
\text { be achieved by expression } \\
\text { profile analysis and } \\
\text { downstream protein } \\
\text { isolation and functional } \\
\text { assays. }\end{array}$ & 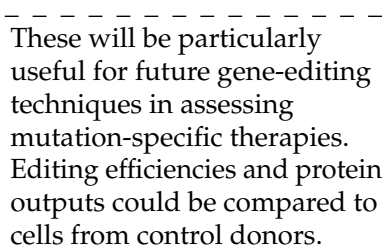 \\
\hline$\overline{\text { Fibroblasts }}-\overline{-}----$ & $\begin{array}{l}-\overline{-}---\overline{-}-\bar{f}- \\
\text { genotype }\end{array}$ & $\begin{array}{l}\text { Some retinal gene } \\
\text { expression may be evident, } \\
\text { as for } A B C A 4[41] .\end{array}$ & $\begin{array}{l}\text { Functional outputs could } \\
\text { be achieved by expression } \\
\text { profile analysis and } \\
\text { downstream protein } \\
\text { isolation and functional } \\
\text { assays. }\end{array}$ & $\begin{array}{l}\text { The use of these will likely be } \\
\text { supplementary to preliminary } \\
\text { pre-clinical assessments of } \\
\text { new therapies as expression of } \\
\text { retinal genes will be limited. } \\
\text { However, being } \\
\text { patient-derived, they will have } \\
\text { the added benefit of being } \\
\text { useful for gene-editing } \\
\text { strategies. }\end{array}$ \\
\hline$\overline{\text { Hair follicles }}----$ & $\begin{array}{l}-----\overline{-}-\overline{-} \\
\text { Patient-specific } \\
\text { genotype }\end{array}$ & 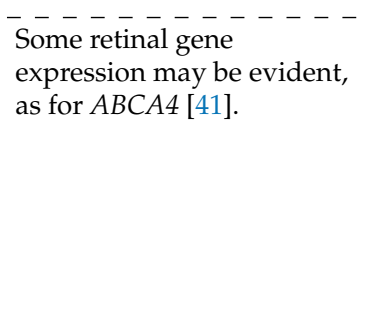 & $\begin{array}{l}------------ \\
\text { As for fibroblast samples, } \\
\text { functional outputs could } \\
\text { be achieved by expression } \\
\text { profile analysis and } \\
\text { downstream protein } \\
\text { isolation and functional } \\
\text { assays. }\end{array}$ & $\begin{array}{l}\text { As for fibroblast samples, the } \\
\text { use of these will likely be } \\
\text { supplementary to other } \\
\text { preliminary pre-clinical } \\
\text { assessments but being } \\
\text { patient-derived they will have } \\
\text { the added benefit of being } \\
\text { useful for gene-editing } \\
\text { therapies. }\end{array}$ \\
\hline$\overline{\text { Retinal organoids }}-\overline{-}$ & $\begin{array}{l}\text { Patient-specific } \\
\text { genotype }\end{array}$ & $\begin{array}{l}\text { Structural differences may } \\
\text { be evident and include } \\
\text { protein mislocalisation } \\
\text { [42-49]. }\end{array}$ & $\begin{array}{l}\text { As for other } \\
\text { patient-derived samples, } \\
\text { functional outputs could } \\
\text { be achieved by expression } \\
\text { profile analysis and } \\
\text { downstream protein } \\
\text { isolation and functional } \\
\text { assays. }\end{array}$ & $\begin{array}{l}\text { Changes in expression profiles } \\
\text { and protein localisation plus } \\
\text { cell morphology could be } \\
\text { assessed following treatment } \\
\text { application. Retinal organoid } \\
\text { will provide an ideal model for } \\
\text { mutation-specific treatments. }\end{array}$ \\
\hline
\end{tabular}

\section{Gene Therapy for Stargardt Disease}

With dozens of clinical trials ongoing and an approved gene therapy treatment for inherited retinal disease, the evidence of safety and efficacy of such an approach is building year on year. The focus to date has been on gene supplementation strategies for genes that cause autosomal recessive disease (for example, RPE65 [50]) and X-linked disorders (for example, CHM [51] and RPGR [52]), which by their nature are amenable to such an approach. STGD1 would be considered a strong candidate for a gene supplementation strategy, but the large $6.8 \mathrm{~kb}$ coding sequence of $A B C A 4$ leads to difficulties in gene delivery, as the favoured vector is adeno-associated virus (AAV), which has an optimal packaging capacity of $\sim 4.7 \mathrm{~kb}$ [53]. This has led to various strategies being developed to enable large gene delivery. By comparison, both ELOVL4 and PROM1 coding sequences are of a size that would package well into AAV, but as they are mainly autosomal dominant diseases with associated dominant negative mechanisms [23], gene supplementation would not likely resolve the disease condition. In the absence of generic pharmaceutical intervention, treatment options for STGD3 and STGD4 are therefore likely going to rely on future gene-editing technology (discussed later). 


\subsection{Lentiviral Vectors}

Lentiviral vectors have been of interest for gene therapy due to their packaging capacity of $\sim 8 \mathrm{~kb}$, enabling them to carry even the largest coding sequences, including $A B C A 4$. Equine infectious anaemia virus (EIAV) lentiviral vectors were shown to successfully transduce mouse [54] and macaque retina [55]. A full-length $A B C A 4$ coding sequence was packaged into EIAV-derived lentiviral vectors and delivered by subretinal injection into post-natal day 5 (P5) Abca $4 \mathrm{KO}$ mice [56]. The transgene included a LacZ reporter and a correlation between ABCA4 protein expression and LacZ $Z$ was achieved in treated eyes. Expression was sustained over 12 months and indications of a reduction in A2E accumulation were also achieved. It should, however, be noted that at P5, photoreceptors are still mitotic in the mouse retina and do not yet elaborate outer segment discs. These key anatomical features are likely to make it much easier for the cell-membrane enveloped lentiviral vectors to transduce immature photoreceptor cells compared with the adult, because the cell bodies of the latter are separated from the subretinal space by the dense lipid bilayers of up to 1000 compacted outer segment discs [57]. In a follow-up study, adult macaque and rabbit eyes were injected with GFP-EAIV or ABCA4-EAIV, respectively, without the LacZ reporter [55]. The EAIV lentiviral vectors were well tolerated in both species with only slight signs of inflammation in injected eyes. This became the StarGen vector (Sanofi, Oxford Biomedica, Oxford, UK), and in 2011 a Phase I/II clinical trial was initiated (NCT01367444). The trial was terminated in 2019 with study data on 27 patients reported online in June 2020 (https: / / clinicaltrials.gov/ct2/show/record /NCT0136744 4 ? cond $=$ Stargardt + Disease\&draw $=2 \&$ rank $=7$, accessed on 30 June 2021). Serious adverse events were listed in two individuals, these being increased intraocular pressure in one and uveitis in another. All patients suffered one or more (not serious) adverse events but until the study is peer-reviewed, no conclusions can be drawn. With early termination of this study due to withdrawal of the sponsor Sanofi, all patients have been transferred to a 15-year follow-up (NCT01736592).

Despite their useful packaging capacity, the size and viral structure appear to limit the transduction capacity of lentiviral vectors in the retina [58]. With an absence of efficacy data from the clinical trial there is currently little encouragement for continued use of these vectors for Stargardt disease gene therapy. Whilst the interest in these vectors has waned in the last decade, the use of AAV vectors has accelerated.

\subsection{Adeno-Associated Viral Vectors}

Within the field of gene therapy, AAV vectors have been used extensively for therapeutic transgene delivery and in clinical trials for retinal disease they have shown good safety with minimal adverse events [59]. In the case of STGD1 treatments, early attempts involved creation of a single "oversized" transgene containing the complete $6.8 \mathrm{~kb} A B C A 4$ coding sequence. When combined with other required transgene elements, this generated a transgene of over $10 \mathrm{~kb}$. Attempts were made to package such oversized transgenes into AAV vectors and transduction of these preparations did enable production of the fulllength protein both in vitro and in vivo [60]. However, the unregulated nature of the AAV packaging process meant that a heterogenous population of truncated transgenes were contained in the AAV capsids, leading to it being referred to as a fragmented dual-vector approach [61-63]. It was determined that the success of the approach came from AAV capsids containing transgenes that by chance happened to contain overlapping regions of sequence [64]. Assessments of a fragmented AAV-ABCA4 preparation revealed that in addition to forming the desired full length $A B C A 4$ transcript following recombination of overlapping truncated transgenes, hybrid transcripts of truncated fused $A B C A 4$ sequence were also present, of which some contained inserts of the AAV genome [65]. Despite the initial signs of success in attempting to package an oversized AAV transgene containing the complete $A B C A 4$ coding sequence, it became apparent that this approach was not going to be feasible due to the inability to reliably prepare homogenous AAV preparations contain- 
ing defined transgenes. Given the anticipated treatment benefits of providing functional $\mathrm{ABCA4}$, a shift was therefore made to dual AAV vector strategies.

Dual vector AAV strategies can take various forms, employing different mechanisms for formation of a single complete therapeutic element from two vectors [66]. One method uses the principle of overlapping regions that provided the success of the above fragmented strategy but with optimised and defined regions of coding sequence overlap [67,68] An alternative early approach was named trans-splicing and it provided no regions of overlap between the two transgenes but instead relied on the native tendency of transgenes to concatamerise via the inverted tandem repeat (ITR) elements that cap each end of a transgene $[69,70]$. Following joining of two transgenes via ITRs, splice donor and acceptor sites on either side of the fused ITR would enable removal of these extra sequences, leaving an intact full-length coding sequence. As with the overlapping dual vector approach, trans-splicing attempts to deliver full-length $A B C A 4$ showed early signs of success in mouse and pig models $[67,71]$. However, it is not possible to control concatamerisation; therefore, correct and incorrect orientations of concatamerised transgenes were achieved [72-74]. As a successful treatment would employ reliable mechanisms to enable success, the trans-splicing approach was combined with the overlapping principle to form a hybrid strategy [75]. This placed an overlapping sequence of homology between the splice sites on opposite transgenes, enabling reconstituted transgene formation by both the overlapping and trans-splicing mechanisms. Whereas the original overlapping strategy relied on using the coding sequence as overlap, hybrid dual vectors provided an opportunity to assess recombinogenic sequences of different origin $[76,77]$.

All three dual vector strategies have successfully led to full-length ABCA4 expression in the $A b c a 4 \mathrm{KO}$ mouse model and provided evidence of efficacy by way of reduced bisretinoid/A2E/lipofuscin accumulation $[67,68,78]$. One of the earlier studies initially suggested an overlapping strategy might not be viable for photoreceptor targeting [67]. Wild-type mice injected with AAV8 overlapping $A B C A 4$ vectors failed to produce fulllength $A B C A 4$ in eyes injected with $1 \times 10^{9}$ genome copies per vector per eye when using either rhodopsin or rhodopsin kinase promoters (photoreceptor cell-specific promoters). However, $79 \%$ of injected eyes (11 of 14) did generate full-length ABCA4 when the ubiquitous CMV promoter was used. This led to a focus on trans-splicing and hybrid dual $A B C A 4$ vectors and it was found that when injected in albino $A b c a 4 \mathrm{KO}$ mice and incorporating the rhodopsin promoter, $18 \%$ of eyes achieved full-length ABCA4 protein from the transsplicing dual vector and $50 \%$ of eyes with the hybrid vector. Further to this, treated eyes showed a significant reduction in lipofuscin granules compared to untreated eyes. With the hybrid dual vector appearing to work best in this study, the researchers performed optimization in attempts to increase the efficacy [78]. Both aspects of hybrid dual vector recombination mechanisms were considered by comparisons of different ITR structures and the region of homology between transgenes. It was identified that homologous ITRs from the AAV2 genome were preferred for concatamerisation and that the F1 phage region of homology provided better recombination rates than an alkaline phosphatase sequence. This time, the rhodopsin kinase promoter was used with $2 \times 10^{9}$ genome copies per vector per eye injected in wild-type mice. In this cohort, $50 \%$ of eyes generated full-length ABCA4 with variable expression levels evident between eyes. This was similar to the original findings and pigmented Abca4 $\mathrm{KO}$ mice were subsequently injected with $1.8 \times 10^{9}$ genome copies per vector per eye. At 3 months post injection the presence of lipofuscin in the RPE was measured using fluorescence intensity of eye tissue cryosections. The results suggest the RPE fluorescence intensity was significantly higher in untreated areas of retina than treated areas. These data were encouraging, but the fluorescence intensity measurement is difficult to standardise and since this study, more reliable methods of bisretinoid/A2E/lipofuscin accumulation have been employed, such as the previously mentioned SLO assessment of autofluorescence [28] and HPLC quantification of retinal tissue [27]. 
Despite the original lack of success with overlapping $A B C A 4$ dual vectors [67], it was considered that a viable strategy could still be obtained but that the success may lie in the region of homology between the two transgenes. A number of overlapping $A B C A 4$ coding sequence options were therefore compared, ranging from 1.17 to $0.09 \mathrm{~kb}$ in length with the optimal length identified to be $0.2 \mathrm{~kb}$ [68]. In addition to optimising the rate of recombination, truncated ABCA4 protein produced from the $3^{\prime}$ vector was successfully ablated by ensuring that the packaged coding sequence contained an out-of-frame "ATG" nucleotide sequence downstream of the 5'ITR prior to an in-frame "ATG" codon. The rhodopsin kinase promoter was used with transgenes packaged in the AAV8 Y733F serotype. Fulllength ABCA4 was achieved in $90 \%$ of injected pigmented Abca4 KO eyes when a high dose of $1 \times 10^{10}$ genome copies per vector per eye was delivered. Protein lysate assessments indicated the total global levels of ABCA4 in injected eyes was $1-10 \%$ of that in wild-type eyes, yet in the region of injection, immunostaining suggested levels of ABCA4 in the photoreceptor outer segments were comparable to those of wild-type photoreceptors. Furthermore, in a blinded study, bisretinoid and A2E levels were compared by HPLC quantification of dual-vector-treated and paired sham-injected eyes 3 months post injection. Levels of bisretinoids / A2E were significantly reduced in the treated eyes, which aligned with the $790 \mathrm{~nm}$ (lipofuscin-related) SLO assessments that identified significantly less autofluorescence developed between 3 and 6 months post injection in dual-vector-treated eyes compared to paired sham-injected eyes.

A similar study used AAV8 Y733F to deliver a hybrid $A B C A 4$ dual vector system containing an alkaline phosphatase sequence for recombination [78]. Pigmented $A b c a 4 \mathrm{KO}$ mice were injected with $3 \times 10^{9}$ genome copies per vector per eye and at 4 weeks post injection full-length ABCA4 was detected at levels $<20 \%$ of wild type. This study assessed relative A2E levels by $488 \mathrm{~nm}$ SLO measurements taken at 1, 2, 3, 4 and 5 months post injection. Levels of autofluorescence were significantly reduced in treated eyes compared to paired untreated eyes from 2 months post injection, which was maintained to 5 months post injection. At this latter time point, A2E levels were quantified by HPLC analysis and determined to be significantly reduced in the treated eyes.

A more recently described dual vector strategy involves intein-mediated reconstitution. Whereas overlapping dual vectors form the full-length $A B C A 4$ at the DNA phase and trans-splicing vectors at the RNA level, the intein strategy involves full-length ABCA4 reconstitution at the protein level [66]. Split N- and C-terminal intein polypeptides are added to the relevant extremities of each fragment of the ABCA4 protein. Upon interaction, the intein is removed by native cell processes and the two ABCA4 polypeptides combine to form the required therapeutic full-length protein. As with overlapping dual vectors, determining the optimal sequence and splitting point of the peptides will be crucial and likely gene/protein dependent [79]. One of the risks with this approach is that the tertiary structure and ultimate function of a given protein relies on post-translational modifications that may occur differently if two fragments are made separately and then combined. However, preliminary experiments have indicated highly encouraging results with fulllength ABCA4 efficiently produced in retinal organoids and the treated eyes of mice and pigs [79]. Multiple splitting points for the $A B C A 4$ coding sequence were compared and the optimised $A B C A 4$-intein dual vector system was injected into wild-type mice at $3.3 \times 10^{9}$ genome copies per vector per eye. At 4-7 weeks post-injection, full-length ABCA4 protein (expression driven from the rhodopsin kinase promoter) was identified in 10 of 11 treated eyes, which also revealed high levels of truncated polypeptides from each single vector. An $A b c a 4 \mathrm{KO}$ cohort injected with $4.3 \times 10^{9}$ genome copies of the $5^{\prime}$ vector and $4.8 \times 10^{-9}$ genome copies of the $3^{\prime}$ vector was assessed at 3 months post injection for lipofuscin accumulation. In this study, such measurements were made by lipofuscin granule counts by electron microscopy, which were significantly reduced in treated eyes compared to sham-injected eyes.

Collectively, these pre-clinical studies provide great encouragement for dual-vector strategies, although it should be noted that they vary in study design and post-treatment 
measurements in ways that make comparisons between efficacy data difficult to compare directly. For example, not all pre-clinical studies have compared treated eyes to shaminjected eyes. As a subretinal injection can cause a degree of change to the retina, it seems important to aim for a sham injection control. Additionally, measurements by SLO can be prone to bias, particularly in exposure levels between opposing eyes; therefore, conducting such assessments in a blinded manner should be strongly considered. An additional study feature could be to inject treatment and sham material into alternate contralateral eyes within a cohort to avoid further image bias.

Despite the variations in approach and specific methodologies used to measure posttreatment changes in bisretinoid/A2E/lipofuscin accumulation, the consistent success of the dual-vector strategies offer great hope for clinical trial initiation. All dual AAV vector systems carry risks of unwanted expression products, which have been evident in intein [79], overlapping, trans-splicing and hybrid $A B C A 4$ dual AAV vectors from both the $5^{\prime}$ elements $[77,80]$ and the $3^{\prime}$ elements $[68,77,81]$. Prior to clinical trial, it needs to be shown that each component is safe as a single vector as well as when applied in combination, which so far has been presented for an overlapping $A B C A 4$ dual AAV system [82]. As described above, this dual-vector system was optimised to reduce/limit unwanted expression products [68], making each single-vector component inert until provided in combination. Such steps will be crucial for any dual AAV vector strategy before testing in humans.

A dual-vector system will inevitably be less efficient than a traditional single AAV strategy, achieving in the studies described above between 1 and 20\% of wild-type levels of ABCA4 in treated eyes. However, whilst STGD1 onset occurs early in life, the rate of progression is typically slow. Understanding the biomolecular mechanisms of disease provides confidence that expressing any level of functional ABCA4 should be beneficial as it would reduce the rate of bisretinoid build-up that leads to retinal dysfunction and degeneration. The pre-clinical data now available provide encouraging signs that a dualvector clinical trial for STGD1 could be worth pursuing.

\subsection{Nanoparticles}

Given the limitations of the viral vector delivery methods discussed, nanoparticles offer an alternative carrier for larger transgenes. Whereas viral vectors for inherited retinal disease may trigger an immune response [83,84], such responses would not be anticipated from artificial nanoparticles. Nanoparticles are cationic compounds that get wrapped in negatively charged DNA, typically in plasmid form, which provides a degree of protection from nuclease-mediated degradation whilst enabling passage through cell membranes by endocytosis or receptor-mediated uptake. The first nanoparticles used for ABCA4 delivery were polyethylene glycol-substituted polylysine (CK30PEG) with a packaging capacity range of 5-20 kb [85]. Abca4 $\mathrm{KO}$ mice received subretinal injection of nanoparticles coated with plasmid carrying a complete $A B C A 4$ transgene containing either the interphotoreceptor-binding protein (IRBP) promoter or the mouse opsin promoter. Fulllength ABCA4 protein expression was achieved up to 8 months post injection with peak expression observed at 2 months. Lipofuscin granules in the RPE were also reduced in treated Abca4 KO eyes compared to untreated eyes. These data suggest that nanoparticles could deliver plasmid DNA to the photoreceptor cells of the retina and provide long-term expression of the desired therapeutic product. However, a further example of $A B C A 4$-nanoparticle delivery to photoreceptor cells was not achieved until more recently [86]. A new preparation of $\mathrm{pH}$-sensitive amino lipid nanoparticles was used of (1-aminoethyl)iminobis [N-(oleoylcysteinyl-1-amino-ethyl)propionamide) (ECO), which not only self-assemble with the DNA but also enable amphiphilic endosomal escape and reductive cytosolic release [87,88]. Pigmented Abca4 KO mice were injected with ECO nanoparticles carrying compact plasmid DNA containing the bovine rhodopsin (RHO) promoter with the full-length $A B C A 4$ coding sequence. At 4 days post injection, levels of $A B C A 4$ mRNA were 500-2500 fold greater than untreated eyes but by 4.5 months post 
injections, $A B C A 4$ mRNA levels were 2-15 fold above background. No evidence of ABCA4 protein expression was provided but there was an indication of reduced $\mathrm{A} 2 \mathrm{E}$ accumulation in ECO-RHO.ABCA4 treated eyes relative to untreated eyes 8 months post injection. No signs of toxicity were evident, but this was not specifically assessed in the study and needs further investigation. Given the encouraging recent attempts to enhance and optimise the formulation [89], these ECO nanoparticles seem a promising approach to pursue for supplementation of ABCA4.

\subsection{Anti-Sense Oligonucleotides}

Anti-sense oligonucleotides (AONs) are small, single-stranded fragments of artificial nucleotides that act as RNA modulators [90]. They bind to complementary nucleotides of either mRNA or pre-mRNA, enabling prevention of splicing at deep intronic premature splice sites or to enforce exon skipping to prevent toxic protein production. Their potential use for the treatment of Stargardt disease is endorsed by data from the ongoing clinical trial (NCT03140969). Patients with the deep intronic mutation c.2991 + 1655A > G in CEP290, which causes the inherited retinal dystrophy Leber congenital amaurosis, have so far received an intravitreal injection of sepofarsen (ProQR Therapeutics), a 17-mer 2'-O-methylmodified phosphonothioate RNA AON, followed by three monthly top-up injections. Importantly, no serious adverse events have been reported with encouraging signs of improvements to visual acuity at 3 months post treatment [91]. More recently, it was revealed that one patient achieved a sustained response to just a single dose of sepofarsen lasting up to 15 months after treatment [92]. These clinical trial data suggest that such intervention in Stargardt patients could also be achievable. Prior to the sepofarsen clinical trial, there were some concerns about delivering AONs to the eye regarding potential inefficient uptake and degradation. However, pre-clinical assessments consistently showed the precursor to sepofarsen was taken up by cells and able to reduce levels of the mutant CEP290 variant [93]. Structural modifications have since occurred to improve the efficacy, with the clinical trial data proving the safety and success of the strategy.

An AON therapeutic strategy is not likely to be relevant for STGD3 as ELOVL4 mutations identified to date cause loss-of-function or dominant-negative changes to the protein [94]. However, STGD4 can arise due to splice site mutations and indeed a deep intronic PROM1 mutation caused by pseudoexon activation has been described [95] and would be amenable to an AON strategy. However, it is STGD1 that will have the largest patient cohort for AON treatment and there have been multiple reports of deep intronic mutations that respond to AON therapy in pre-clinical testing. This has been achieved in photoreceptor precursor cells generated from patient skin biopsies [96-98] and with midigene assays in HEK293T cells [98,99].

Another use of AONs for gene therapy has emerged by way of endogenous adenosine deaminase acting on RNA (ADARs) [100]. These enable mutation-specific base editing to reverse guanosine $>$ adenosine mutations, performing the adenosine $>$ inosine transition with inosine then read as guanosine. There are two known endogenous ADARs: ADAR1 and ADAR2. ADAR1 has two isoforms and is ubiquitously expressed but is limited to editing non-coding and repetitive regions of sequence [101]. ADAR2 has one predominant isoform and is the variant harnessed for base-editing interventions as it targets coding regions [102]. It has been shown that ADAR2 RNA is expressed in the retina with immunohistochemical staining identifying ADAR2 in the retinal ganglion cells but as yet expression in other cell types has not been revealed [103]. Given that ABCA4, ELOVL4 and PROM1 are all expressed in the photoreceptor cells, recruitment of endogenous ADAR2 can only be feasible if it is expressed in these cells, whereas ADAR1 may be useful for targeting intronic variants. Different RNA structures for recruiting endogenous ADARs have been assessed, varying from long RNA (71-191 nucleotides) for the Leveraging Endogenous ADAR for Programmable Editing of RNA (LEAPER) system [104] to the shorter 20-40 chemically modified nucleotides used for the Recruiting Endogenous ADAR to Specific Transcripts for Oligonucleotide-mediated RNA Editing (RESTORE) system [100]. It is also possible 
to attract endogenous ADAR by incorporating recruitment domains [105]. Whilst there is potential in an RNA base-editing strategy for Stargardt disease [4,106], until more is known about the endogenous ADAR expression profile in the retina, it may be that co-delivery of base editors with guiding RNA sequences will be required (see later discussion).

\section{Small Molecule Therapy for Stargardt Disease}

\subsection{Pharmaceutical Interventions}

Small molecule therapies enable targeting of a particular step in the visual cycle or aspect of retinal function that is altered by Stargardt disease. Whilst these are not likely to be curative, they aim to reduce symptoms and inhibit progression of the disease. Given the complexity of the visual cycle and the differing roles of ABCA4, ELOVL4 and PROM1, finding suitable generic candidates has proven difficult. However, there are currently multiple clinical trials involving compound therapies that intervene in key pathological pathways that occur in Stargardt disease.

As described earlier, in the case of STGD1, mutations in ABCA4 result in a nonfunctional protein, thereby limiting or abolishing the normal transport of $N$-retinylidenephosphatidylethanolamine. This leads to build-up of all-trans-retinal in the intradiscal space in addition to reducing the clearance rate of $N$-retinylidene-phosphatidylethanolamine (NretPE), which causes the generation of A2PE in the disc membranes. The combination of these events leads to generation of $N$-retinylidene-N-retinylethanolamine (A2E), a major component of lipofuscin that accumulates in the cells of retinal pigment epithelium following disc phagocytosis (Figure 2) [107]. The majority of ongoing clinical trials aim to influence this process in various ways. For example, emuxistat hydrochloride is a visual cycle modulator that is a direct inhibitor of the visual cycle component retinol isomerase RPE65 [108] and in so doing slows the regeneration of 11-cis-retinal, reducing production of retinaldehyde, but it has also been shown to sequester the cytotoxic all-trans-retinal [109]. Patients with confirmed mutations in ABCA4 were recruited for a Phase IIa trial in 2017 (NCT03033108) and received either a daily dose of 2.5, 5 or $10 \mathrm{mg}$ oral emuxistat for one month. Delayed dark adaption was reported in $47 \%$ of participants, occurring most frequently in the $5(67 \%)$ and $10 \mathrm{mg}(57 \%)$ cohorts. Suppression of the rod photoreceptor b-wave was therefore dose dependent and confirmed the biological activity of emuxistat [110]. This delayed dark adaptation was a consequence of the drug's mechanism of action and not a treatment effect, but with the absence of other adverse events a Phase III trial was initiated that will investigate the efficacy of the $10 \mathrm{mg}$ dose in STGD1 patients (NCT03772665). It is worth noting that emuxistat trials have also occurred for patients with age-related macular degeneration, but data following a 24 month randomised clinical trial revealed emuxistat did not reduce the growth rate of geographic atrophy in such patients. However, given the complex, late-onset and multifactorial nature of the disease, this does not suggest that such trials in STGD1 patients will not be effective.

The build-up of A2E and other bisretinoids can lead to activation of the complement system in RPE cells [111] and complement inflammatory markers have been identified as elevated in the Abca4 KO model [112]. Complement activation is highly involved in the aetiology of age-related macular degeneration [113], and given the shared features between age-related macular degeneration and STGD1, drugs designed for one may be relevant to the other. Avacincaptad pegol (Zimura) is an anti-C5 aptamer that aims to prevent or reduce the destructive effects of the activated complement cascade. Avacincaptad pegol has been provided as an intravitreal injection to Phase IIb clinical trial patients (NCT03364153); recruitment of 120 STGD1 patients began in 2018 with results yet to be reported. However, data from a Phase II/III trial in 286 patients with age-related macular degeneration determined the drug was well tolerated with evidence of efficacy achieved. Indeed, a significant reduction in the growth rate of geographic atrophy (by $27 \%$ ) was observed in patients that received either 2 or $4 \mathrm{mg}$ doses [114]. These encouraging data enable a degree of optimistic anticipation for the forthcoming results of the ongoing trial for STGD1. Another drug, eculzimab, has been explored for C5 inhibition but this is an IgG 
antibody, and though well tolerated in a Phase II clinical trial (NCT00935883), no signs of efficacy were achieved in patients with age-related macular degeneration [115] and there appear to be no indications of further trials in other cohorts.
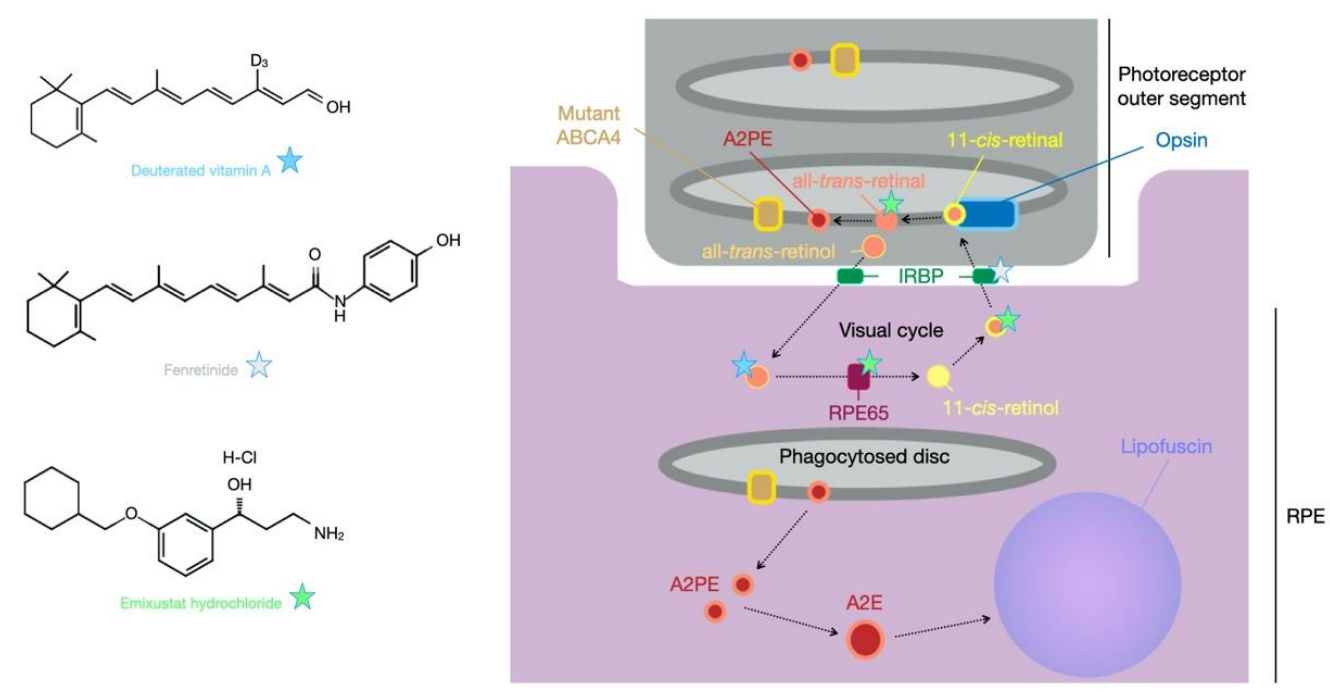

Figure 2. Example pharmaceutical interventions for Stargardt disease. Treatment strategies for STGD1 include pharmaceutical products that interfere with the biochemical pathways that lead to the disease state. IRBP = interphotoreceptor retinoid-binding protein; RPE = retinal pigment epithelium; RPE65 = retinoid isomerohydrolase.

A common target of the visual cycle is vitamin A (all-trans-retinol), which is a precursor to 11-cis-retinol. It is postulated that reducing levels of vitamin A could limit the production of all-trans-retinal/PE and subsequently A2E. Whilst supplements of standard vitamin A may be detrimental, as observed in the $A b c a 4 \mathrm{KO}$ model [25], an alternative approach has been the provision of deuterated vitamin A (ALK-001). This drug has the C20 hydrogen atoms replaced with deuterium atoms, an isotope of hydrogen with a neutron in the nucleus, Figure 2. This impedes the dimerization of vitamin A and therefore reduces the opportunity for production of A2E [116]. Dietary provision of C20-deuterated vitamin A has been shown in Abca4 KO mice to prevent the disease phenotype [117]. The tight dietary control required to achieve these results in mice may not be feasible in humans, but a Phase I clinical trial (NCT02230228) has at least shown oral ingestion of C20-deuterated vitamin A to be safe. A Phase II trial for STGD1 patients is ongoing (NCT02402660) with preliminary data presented at the 2019 ARVO Annual Meeting [118]. It was considered that $90 \%$ of dietary vitamin A intake had been replaced by deuterated vitamin A with no unexpected adverse events reported. No data relating to efficacy have been provided to date, but a new clinical trial has been initiated to extend the assessments of tolerability and efficacy of ALK-001 (NCT04239625). Another vitamin A-related treatment potential for STGD1 is fenretinide (Sirion Therapeutics), which is a synthetic derivative of vitamin A that binds retinol-binding protein and reduces the circulating levels of this protein, which in turn decreases levels of vitamin A and subsequently A2E in Abca4 KO mice [119]. Whilst no trials have been initiated with STGD1 patients, a Phase II trial of 246 patients with age-related macular degeneration (NCT00429936) identified adverse events in $20 \%$ of the high-dose cohort (300 mg daily oral dose) for whom treatment was stopped. Serum levels of retinol-binding protein were reduced in a dose-dependent manner, but evidence of efficacy was not significant [120]. The drugs A1120 and STG-001 (Stargazer Pharmaceuticals) are also inhibitors of retinol-binding protein. In contrast to fenretinide, A1120 is a nonretinoid retinol-binding protein antagonist that reduced the accumulation of lipofuscin in the Abca4 KO model with no significant impact on ERG [121]. It was shown not to act as a retinoic acid receptor alpha agonist, which may potentially improve its safety profile in comparison to fenretinide, but until clinical trials are attempted, this is difficult 
to infer. Minimal information is available on the drug STG-001 other than the knowledge that it is an inhibitor of retinol-binding protein and for which a safety trial in healthy individuals has been completed (ACTRN12619000816156) with no release of data. However, a subsequent trial for STGD1 patients was initiated in July 2020 with no findings yet presented (NCT04489511).

\subsection{Dietary Supplementation}

Other small-molecule clinical trials ongoing for Stargardt disease involve dietary supplements. Docosahexaenoic acid (DHA), eicosapentaenoic acid (EPA) and alpha-linolenic acid (ALA) are omega-3 fatty acids. DHA is the major very-long-chain polyunsaturated fatty acid of the retina and is a particularly critical component of photoreceptor cells [122]. Dietary DHA supplementation was investigated in STGD1 and STGD3 patients to determine whether macular function could be improved (NCT00060749). Trial data relating to the STGD1 patients recruited have been reported: patients received DHA supplementation ( $2000 \mathrm{mg}$ /day) followed by 3 months of placebo, which was repeated to form a 12-month period with no improvement in macular function observed in the small cohort recruited (11 subjects) [123]. This STGD1 cohort was recruited on the hypothesis that dietary DHA supplementation may cause non-specific effects and would therefore be used as a control sample for the STGD3 cohort, data for which have yet to be revealed. Pre-clinical assessments suggested DHA supplementation had a positive effect on retinal function in heterozygous ELOVL4 knock-in STGD3 mice [35] at 6-12 months of age and preservation of cone function was also achieved in 12-18-month-old wild-type mice [124]. The MADEOS trial (Macular Degeneration Omega-3 study, NCT03297515) is a further trial comparing dietary supplementation of omega-3 fatty acids against a placebo of sunflower oil and will include patients with age-related macular degeneration and Stargardt disease.

A final dietary supplementation used in clinical trials in attempt to counteract oxidative stress that can induce the accumulation of lipofuscin, is saffron (NCT01278277). A total of 31 patients with $A B C A 4$ mutations were randomly assigned to two groups and consumed either $20 \mathrm{mg}$ oral saffron daily for 6 months followed by a switch to the placebo for 6 months (14 patients) or vice versa (17 patients). Macular cone-mediated responses were assessed with no significant findings achieved after 6 months [125]. However, it may be that assessments over a longer period of study would achieve more indications of treatment effect and measurements of autofluorescence were not acquired, which would be a further outcome measure worth pursuing.

\section{Cell Replacement Therapy for Stargardt Disease}

With atrophy of RPE and photoreceptor cells causing loss of visual acuity in patients in later stages of disease, the treatment options considered up to this point would only be beneficial for preventing further sight loss. In order to regain lost vision, transplantation of new cells would be required. Pre-clinical studies providing human embryonic stem cell (hESC)-derived RPE cells into the subretinal space of mice have provided encouraging proof-of-principle data. The hESC-RPE cells were transplanted into the Royal College of Surgeons rat model, which suffers vision deterioration over time due to a mutation in Mertk, a c-mer proto-oncogene kinase receptor specific to RPE cells [126]. Non-functional Mertk causes RPE dysfunction by preventing phagocytosis of shed photoreceptor outer segment discs, which leads to death of the photoreceptor cells. In the RCS rats, optometer responses were used as measurements of visual acuity and animals that received 50-100,000 cells performed significantly better than untreated and sham-injected animals [127]. The hESC-RPE cells were also injected into an STGD3 mouse model with a marginal significant improvement in optomoter responses observed in cell-treated eyes compared to sham-injected and untreated controls at 5 weeks post surgery. These data led to Phase I/II clinical trials (NCT01625559 and NCT01345006) in which late-stage patients with Stargardt's disease received hESC-RPE transplantation. Importantly, no serious adverse events relating to the transplanted cells were reported and best corrected visual acuity 
was increased in transplanted eyes compared to non-transplanted control at 12 months after surgery, although the sample size was too small to determine significance [128]. There have been several similar trials, including NCT01469832, in which 12 STGD1 patients received escalating doses of hESC-RPE cells. Whilst no detrimental effects were identified, improvements in retinal function and visual acuity were not apparent [129]. Follow-up trials to these are ongoing (NCT02445612 and NCT02941991) and will be of particular interest to confirm the safety of such intervention.

A recent report presented data from 17 Stargardt disease patients that received autologous (patient-derived) bone-marrow-derived stem cells (BMSC) in both eyes (NCT01920867) [130]. Whilst the study was open to STGD1, STGD3 and STGD4 patients, the genetic mutation in the patients reported was not specified. The study remains highly controversial because participants had to pay a significant sum to be in the trial, which is against the internationally agreed research ethics guidance defined by the World Medical Association (WMA) in the Declaration of Helsinki. Furthermore, by recruiting only patients who believe the treatment will benefit them and without having any sham-injected controls, the study will be hugely biased towards a placebo effect. This is not to say BMSC transplantation might not be effective, but the study design and recruitment process of a trial should meet international standards.

A key consideration with RPE transplantation for Stargardt disease is that it does not directly approach the cause of the disease, and therefore may not enable long-term effects. Providing RPE cells back into a retina that has lost these cells and the photoreceptor cells in the same area may not be the most therapeutic transplantation option given that in patients with Stargardt disease, the problem arises in the photoreceptor cells. Provision of new iPSC-derived RPE cells may only be a short-term solution, particularly as these cells will be prone to A2E and lipofuscin accumulation, as were the original RPE cells [131]. The clinical trial data for the studies presented here are highly important for determination of the safety of such procedures and may lead the way for other cell transplantation interventions. For example, ReNeuron are undertaking a Phase I/IIa trial in patients with retinitis pigmentosa who will receive a subretinal transplant of human retinal progenitor cells (NCT02464436). If the safety of such transplantation is shown then it may be that future trials could involve patients with Stargardt disease. It is also possible that in the near future, gene-editing correction of patient iPSCs will be performed with subsequent differentiation into retinal progenitor cells that can be transplanted back into the patient [132].

\section{Future Therapy Prospects-CRISPR}

It is apparent that researchers have taken multiple approaches to the problem of vision loss caused by Stargardt disease (Table 2). Many of the treatment options considered show great potential, yet it may be that the most effective therapy is yet to be developed (Figure 3). Much has been written recently about the potential of clustered regularly interspaced short palindrome repeat (CRISPR)-based molecular tools and, in particular, their application for the treatment of inherited retinal disease [133-135]. Given the numerous reviews on this topic it is not necessary to discuss the mechanistic details here, but suffice to say the discovery of CRISPR has expanded treatment potential for currently untreatable diseases. With ever increasing discoveries of new Cas proteins from various bacterial origins and the development of fusion proteins to expand the molecular functions of these proteins, a new era of gene therapy has begun. In the case of Stargardt disease, a large proportion of mutations in ABCA4, ELOVL4 and PROM1 could be targeted with one or more of the currently described CRISPR-based approaches: genome editing, epigenetic repression, base editing or prime editing (Table 3 ).

The original form of CRISPR came by way of active Cas9, which targets DNA and leads to random insertion or deletion (indel) creation that can be used for gene silencing [136]. Alternatively, inactive Cas9 can achieve epigenetic repression known as CRISPR interference (CRISPRi) without needing to edit the DNA sequence [134]. Indel creation is currently being utilised in the EDIT-101 clinical trial to prevent cryptic exon and premature truncation of CEP290 in Leber congenital amaurosis patients carrying the mutation 
c. $2991+1655$ A > G [137]. The outcomes of this first-in-human use of genome editing by CRISPR-Cas9 for an inherited retinal disease will be of great interest in determining the safety of this new form of gene therapy. Due to the nature of the mutation within an intron, direct gene disruption to remove the premature splice junction appears to be an effective strategy for this type of mutation [138]. As gene disruption by indel formation is an uncontrolled event in terms of the edits that arise, such an approach for targeting an exonic mutation would be restricted to an autosomal dominant disorder for which one wild-type copy of a gene would be sufficient to maintain the non-disease state. This would also be relevant for CRISPRi silencing of a mutant allele and ELOVL4 may be an appropriate candidate for such a strategy. As considered earlier in this review, haploinsufficiency is not the underlying mechanism of STGD3, which suggests that silencing production of the mutant form of ELOVL4 may offer therapeutic potential.

STGD4 is an autosomal dominant disorder that predominantly arises due to the mutation c.1117C > T (p.Arg373Cys) in PROM1, although two other missense mutations have also been identified $[139,140]$. The most common mutation of c.1117C $>$ T would confer a $G>A$ change on the complementary strand. This creates an opportunity for a DNA adenine base editor (ABE) to target the complementary strand and perform an $\mathrm{A}>\mathrm{G}$ transition, thus correcting the " $\mathrm{T}$ " back to a " $\mathrm{C}$ " on the reading strand. Cas9-ABE fusion proteins are currently showing potential at such targeted editing and indeed the PROM1 c.1117C > T site occurs within a good editing window for targeting by Cas9 proteins from Streptococcus pyogenes (SpCas9 [141]), Staphylococcus auricularis (SauriCas9 [142]) and a modified variant from Staphylococcus aureus (KKH-SaCas9 [143]). This makes the predominant STGD4 variant potentially treatable by CRISPR base editing. The current limitations of such constructs include their size, as the Cas9 element fused to the base editor make packaging the therapeutic construct into a single AAV vector difficult. However, lentiviral [144] and dual vector solutions are being used successfully [145-147] for delivery of CRISPR constructs as well as nanoparticles [148]; therefore, the gene therapy delivery systems discussed earlier in this review are also relevant to CRISPR therapeutics.

Base editing is also a viable strategy for STGD1. Patients can carry more than one $A B C A 4$ mutation, but as an autosomal recessive condition, the correction of one allele should be enough to provide a therapeutic benefit [149]. However, if two mutations are on the same allele, effective treatment will require the targeting of both. Furthermore, there are hundreds of pathogenic mutations confirmed in $A B C A 4$ (Table 3) and only a subset will be amenable to CRISPR base editing due to the requirement for a protospacer adjacent motif (PAM) sequence upstream of the mutation. In addition to the $A>G$ correction by adenine base editors fused to Cas9, there are also base editors that enable $C>T$ transitions [150]. This enables not only correction of $\mathrm{T}>\mathrm{C}$ mutations but also $\mathrm{A}>\mathrm{G}$ mutations that can be corrected by targeting the complementary strand. Of all the current pathogenic $A B C A 4$ mutations, $63 \%$ are considered to be editable transition variants and indeed correction of the five most common variants would be beneficial for $21 \%$ of patients [4]. Despite the encouraging findings of other STGD1 treatment options being explored, CRISPR base editing appears to be a viable avenue to pursue.

For $\mathrm{G}>\mathrm{A}$ mutations, a further option is to attempt site-directed RNA base editing with adenosine deaminase acting on RNA (ADAR) enzymes fused with an RNA-targeting Cas protein such as Cas13 [106]. Whilst limited to corrections of $G>A$ mutations, the benefit of RNA editing is that it does not directly alter the native DNA and that any edits are transient for the lifetime of the mRNA molecule. In this respect, RNA editing may offer a safer option for correction of $G>A$ mutants. In addition to this, there is no PAM site requirement for Cas13; therefore, in theory, any " $\mathrm{A}$ " can be converted to a " $\mathrm{G}$ " by this approach. Both RNA and DNA base-editing systems currently suffer from bystander activity, in which nearby " $\mathrm{A}$ " can be converted to " $\mathrm{G}$ ", potentially altering the coding sequence and producing a new mutant variant in the attempt to correct one. However, the field is advancing rapidly and new refined options are developing at a quick rate [151], making base editing a likely therapeutic option for Stargardt disease in the near future. 


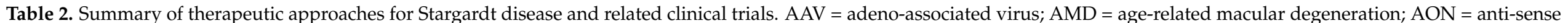

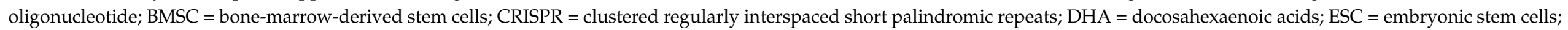
$\mathrm{N} / \mathrm{A}=$ not applicable; RPE = retinal pigment epithelium.

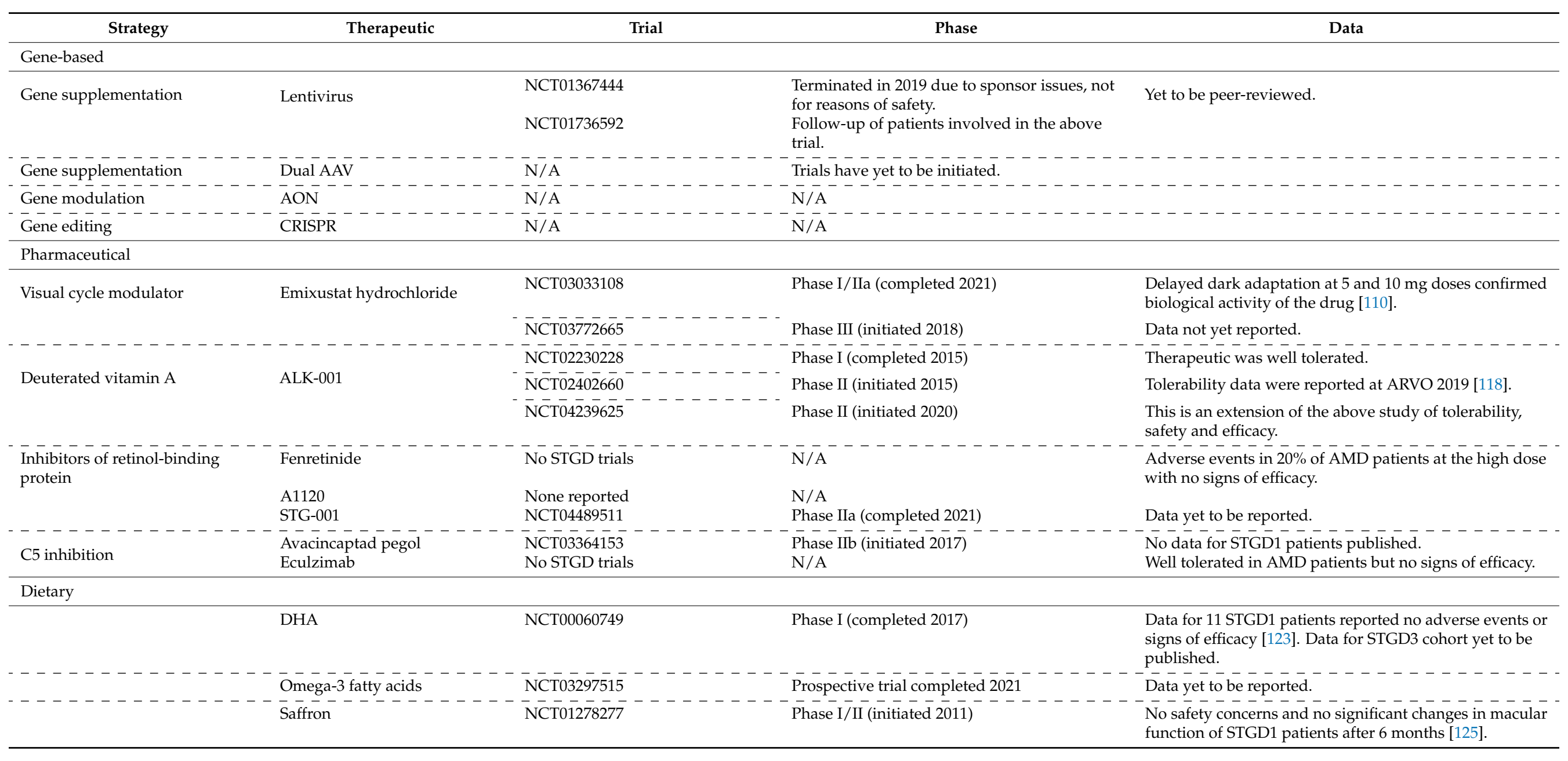


Table 2. Cont.

\begin{tabular}{|c|c|c|c|c|}
\hline Strategy & Therapeutic & Trial & Phase & Data \\
\hline \multicolumn{5}{|l|}{ Cell replacement } \\
\hline \multirow{3}{*}{ ESC-RPE } & \multirow{3}{*}{ MA09-hRPE } & NCT01625559 & Phase I (initiated 2012) & \multirow{3}{*}{$\begin{array}{l}\text { No serious adverse events and no signs of efficacy } 12 \\
\text { months post treatment in advanced STGD1 patients [128]. } \\
\text { Escalating dose of transplanted cells produced no serious } \\
\text { adverse events with no signs of efficacy } 12 \text { months post } \\
\text { treatment in } 12 \text { patients with advanced STGD1 [129]. } \\
\text { Data yet to be reported. }\end{array}$} \\
\hline & & NCT01345006 & Phase I/II (completed 2021) & \\
\hline & & NCT02445612 & $\begin{array}{l}\text { Long-term follow-up to Phase I/II (initiated } \\
\text { 2015) }\end{array}$ & \\
\hline \multirow{2}{*}{----------} & hESC-RPE & NCT02903576 & Phase I/II (completed 2020) & Data yet to be reported. \\
\hline & $\overline{\mathrm{BMSC}}$ & $\overline{\mathrm{NCT}} \overline{-} \overline{1920} \overline{8} \overline{6} \overline{7}$ & Non-randomised open label (initiated 2013) & $\begin{array}{l}\text { Data have been reported but issues exist regarding } \\
\text { recruitment and study design [130]. }\end{array}$ \\
\hline
\end{tabular}


A
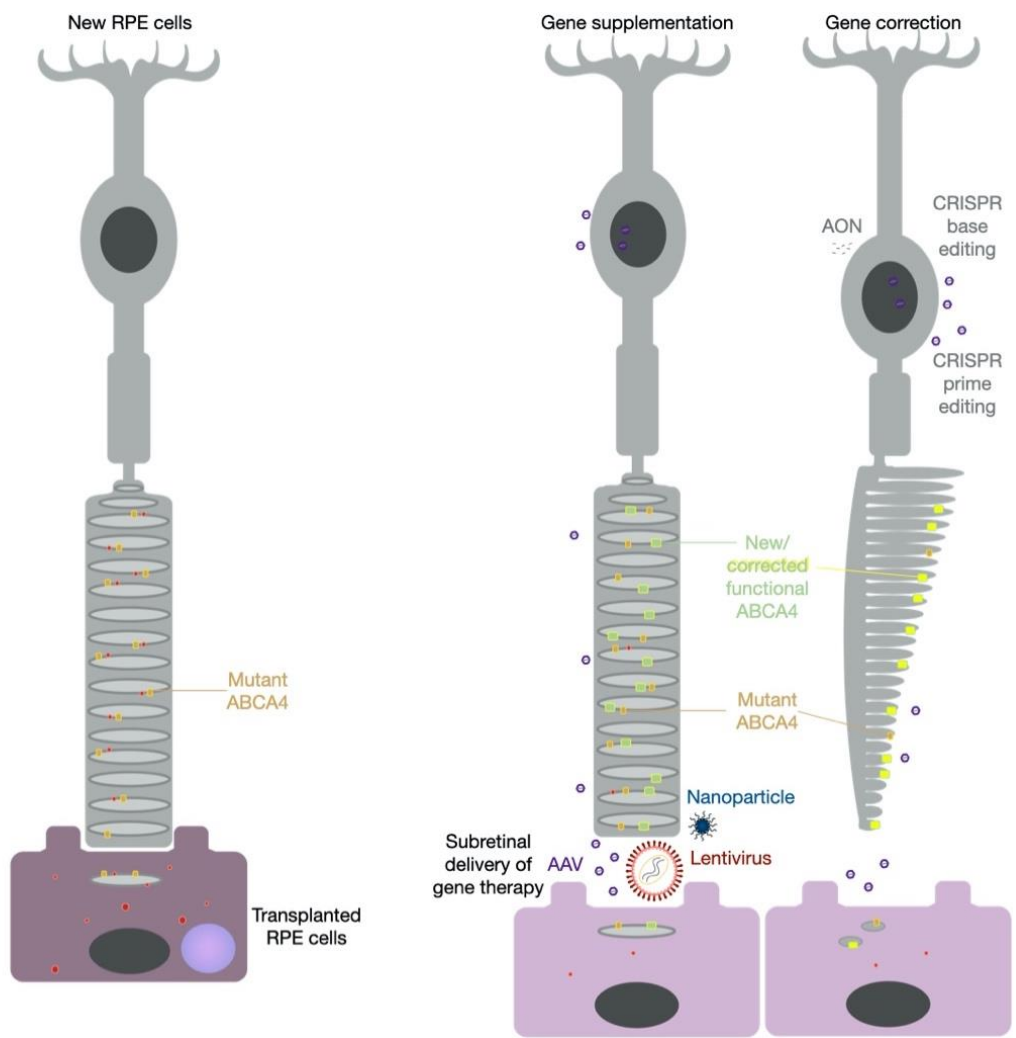

B

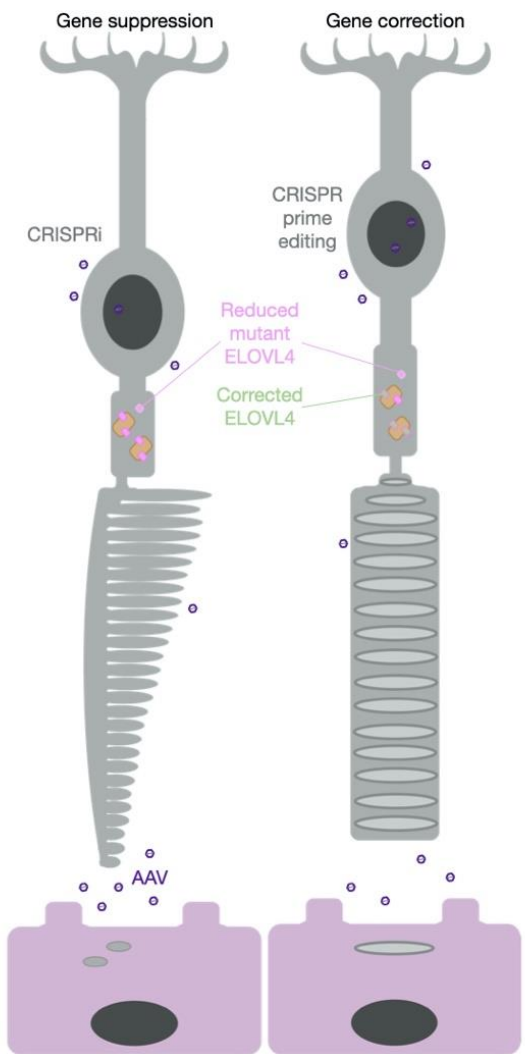

C

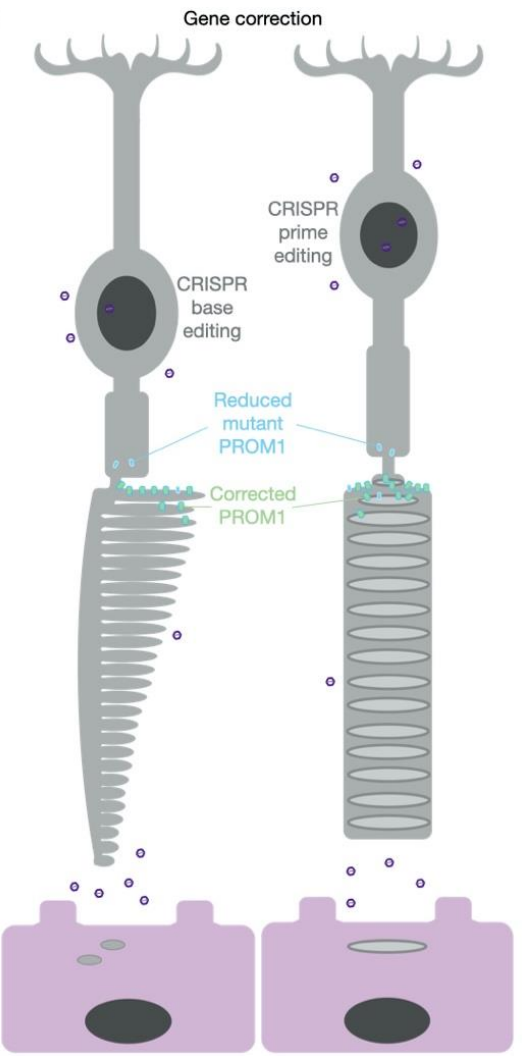

Figure 3. Comparisons of therapy strategies for Stargardt disease. Transplantation of RPE cells has been performed in STGD1 patients with gene supplementation and CRISPR-based genome-editing vectors as future treatment options (A). Therapies for STGD3 (B) and STGD4 (C) will likely focus on CRISPR-based approaches. 
Table 3. Summary of the different types of mutations that cause Stargardt disease. Data were extracted from ClinVar (June 2021) and only included mutations confirmed as pathogenic or likely path-ogenic with evidence of clinical phenotype. Numbers represent the different occurrences of each mutation type; for example, of 349 different $A B C A 4$ mutations, 72 were $\mathrm{G}>\mathrm{A}$ transitions. $\mathrm{ABE}=$ adenine base editor, $\mathrm{CBE}=$ cytosine base editor.

\begin{tabular}{|c|c|c|c|c|}
\hline Mutation & $\begin{array}{l}\text { CRISPR } \\
\text { Strategy }\end{array}$ & $\begin{array}{c}A B C A 4 \\
\text { Total = } 349\end{array}$ & $\begin{array}{c}\text { ELOVL4 } \\
\text { Total = } 23\end{array}$ & $\begin{array}{l}\text { PROM1 } \\
\text { Total }=3\end{array}$ \\
\hline$G>A$ & $\begin{array}{l}\text { ABE (coding } \\
\text { strand) and } \\
\text { RNA-ABE }\end{array}$ & 72 & 3 & 1 \\
\hline$A>G$ & $\begin{array}{l}\text { CBE (non-coding } \\
\text { strand) }\end{array}$ & 21 & 1 & 0 \\
\hline $\mathrm{T}>\mathrm{C}$ & $\begin{array}{l}\text { CBE (coding } \\
\text { strand) }\end{array}$ & 31 & 3 & 1 \\
\hline $\mathrm{C}>\mathrm{T}$ & $\begin{array}{l}\text { ABE (non-coding } \\
\text { strand) }\end{array}$ & 63 & 4 & 1 \\
\hline $\mathrm{G}>\mathrm{T}$ & Prime & 20 & 2 & 0 \\
\hline$G>C$ & Prime & 14 & 0 & 0 \\
\hline $\mathrm{T}>\mathrm{A}$ & Prime & 12 & 0 & 0 \\
\hline $\mathrm{A}>\mathrm{T}$ & Prime & 8 & 1 & 0 \\
\hline $\mathrm{C}>\mathrm{A}$ & Prime & 15 & 2 & 0 \\
\hline $\mathrm{A}>\mathrm{C}$ & Prime & 4 & 1 & 0 \\
\hline$C>G$ & Prime & 13 & 4 & 0 \\
\hline $\mathrm{T}>\mathrm{G}$ & Prime & 17 & 0 & 0 \\
\hline Insert/deletion/duplication & Prime & 59 & 2 & 0 \\
\hline
\end{tabular}

Prime editing is a further CRISPR-based approach worth considering that targets DNA and consists of a Cas9 fused to an engineered reverse transcriptase [152]. In combination with a specially designed prime-editing guide RNA, this enables it to remove mutations and surrounding nucleotides and replace them with corrected sequence. Based on this mode of action, it is not limited to single base transitions but can also resolve transversions, insertions and deletions. With its many complementary components, the on-target editing rates currently appear low compared to other CRISPR approaches, but off-target and bystander editing rates appear reduced and the PAM requirement less stringent [152,153]. This is a new and emerging CRISPR tool for gene therapy with few reports published so far, but given its potential in correcting the vast majority of mutations that cause Stargardt disease, including the most common STGD3 5 bp deletion in ELOVL4 [14], it is an incredibly exciting option for the future.

\section{Concluding Remarks}

Despite the large cohort of Stargardt disease patients, in particular those with STGD1, development of an effective treatment has lagged behind other rarer recessive inherited diseases. As discussed in this review, researchers and clinicians have approached the problem from multiple directions with many therapeutic strategies showing promise. Indeed, some of the options that have shown pre-clinical success have yet to be applied in humans. For all the encouraging therapeutics tested in trials to date, it may be that the most effective treatment form is yet to come by way of CRISPR-based strategies. Regardless of the approach employed, it is clear that with the efforts made so far, there is hope an effective treatment for Stargardt disease will appear in the coming years.

Author Contributions: Conceptualization, E.P., M.E.M. and R.E.M.; writing—original draft preparation, E.P. and M.E.M.; writing-review and editing, E.P., M.E.M. and R.E.M.; funding acquisition, R.E.M. All authors have read and agreed to the published version of the manuscript.

Funding: This research was funded by Retina UK, grant number GR599, and the NIHR Oxford Biomedical Research Centre.

Institutional Review Board Statement: Not applicable.

Informed Consent Statement: Not applicable. 
Data Availability Statement: Not applicable. All data in this review are available from the sources stated in the manuscript.

Conflicts of Interest: M.E.M. and R.E.M. are named inventors on a University of Oxford patent describing the optimised $A B C A 4$ dual AAV vector system (PCT/GB2017/051741). R.E.M. consults for a number of retinal gene therapy companies that may in the future have an interest in Stargardt disease.

\section{References}

1. Cremers, F.P.M.; Lee, W.; Collin, R.W.J.; Allikmets, R. Clinical spectrum, genetic complexity and therapeutic approaches for retinal disease caused by ABCA4 mutations. Prog. Retin. Eye Res. 2020, 100861. [CrossRef] [PubMed]

2. Cornish, K.S.; Ho, J.; Downes, S.; Scott, N.W.; Bainbridge, J.; Lois, N. The Epidemiology of Stargardt Disease in the United Kingdom. Ophthalmol. Retin. 2017, 1, 508-513. [CrossRef] [PubMed]

3. Birtel, J.; Eisenberger, T.; Gliem, M.; Müller, P.L.; Herrmann, P.; Betz, C.; Zahnleiter, D.; Neuhaus, C.; Lenzner, S.; Holz, F.J.; et al. Clinical and genetic characteristics of 251 consecutive patients with macular and cone/cone-rod dystrophy. Sci. Rep. 2018, 8, 1-11. [CrossRef]

4. Fry, L.E.; McClements, M.E.; MacLaren, R.E. Analysis of Pathogenic Variants Correctable with CRISPR Base Editing among Patients with Recessive Inherited Retinal Degeneration. JAMA Ophthalmol. 2021, 139. [CrossRef] [PubMed]

5. Quazi, F.; Lenevich, S.; Molday, R.S. $A B C A 4$ is an N-retinylidene-phosphatidylethanolamine and phosphatidylethanolamine importer. Nat. Commun. 2012, 3, 925. [CrossRef] [PubMed]

6. Beharry, S.; Zhong, M.; Molday, R.S. N-retinylidene-phosphatidylethanolamine is the preferred retinoid substrate for the photoreceptor-specific ABC transporter ABCA4 (ABCR). J. Biol. Chem. 2004, 279, 53972-53979. [CrossRef]

7. Sparrow, J.R.; Wu, Y.; Kim, C.Y.; Zhou, J. Phospholipid meets all-trans-retinal: The making of RPE bisretinoids. J. Lipid Res. 2010, 51, 247-261. [CrossRef] [PubMed]

8. Tsybovsky, Y.; Wang, B.; Quazi, F.; Molday, R.S.; Palczewski, K. Posttranslational modifications of the photoreceptor-specific ABC transporter ABCA4. Biochemistry 2011, 50, 6855-6866. [CrossRef] [PubMed]

9. Sisk, R.A.; Leng, T. Multimodal imaging and multifocal electroretinography demonstrate autosomal recessive stargardt disease may present like occult macular dystrophy. Retina 2014, 34, 1567-1575. [CrossRef]

10. Molday, R.S.; Zhang, K. Defective lipid transport and biosynthesis in recessive and dominant Stargardt macular degeneration. Prog. Lipid Res. 2010, 49, 476-492. [CrossRef]

11. Fritsche, L.G.; Fleckenstein, M.; Fiebig, B.S.; Schmitz-Valckenberg, S.; Bindewald-Wittich, A.; Keilhauer, C.N.; Renner, A.B.; Mackensen, F.; Mößner, A.; Pauleikhoff, D.; et al. A subgroup of age-related macular degeneration is associated with mono-allelic sequence variants in the ABCA4 gene. Investig. Ophthalmol. Vis. Sci. 2012, 53, 2112-2118. [CrossRef]

12. Lindner, M.; Lindner, M.; Lambertus, S.; Maushcitz, M.M.; Bax, N.B.; Kersten, E.; Lüning, A.; Nadal, J.; Schmitz-Valckenberg, S.; Schmid, M.; et al. Differential Disease Progression in Atrophic Age-Related Macular Degeneration and Late-Onset Stargardt DiseaseDisease Progression in AMD and Late-Onset STGD1. Invest. Ophth. Vis. Sci. 2017, 58, 1001-1007. [CrossRef] [PubMed]

13. Agbaga, M.-P.; Brush, R.S.; Mandal, M.N.A.; Henry, K.; Elliott, M.H.; Anderson, R.E. Role of Stargardt-3 macular dystrophy protein (ELOVL4) in the biosynthesis of very long chain fatty acids. Proc. Natl. Acad. Sci. USA 2008, 105, 12843-12848. [CrossRef] [PubMed]

14. Zhang, K.; Kniazeva, M.; Han, M.; Li, W.; Yu, Z.; Yang, Z.; Li, Y.; Metzker, M.L.; Allikments, R.; Zack, D.J.; et al. A 5-bp deletion in ELOVL4 is associated with two related forms of autosomal dominant macular dystrophy. Nat. Genet. 2001, 27, 89-93. [CrossRef] [PubMed]

15. Logan, S.; Agbaga, M.-P.; Chan, M.D.; Brush, R.S.; Anderson, R.E. Endoplasmic reticulum microenvironment and conserved histidines govern ELOVL4 fatty acid elongase activity. J. Lipid Res. 2014, 55, 698-708. [CrossRef] [PubMed]

16. Dejos, C.; Kuny, S.; Han, W.H.; Capel, H.; Lemieux, H.; Sauvé, Y. Photoreceptor-induced RPE phagolysosomal maturation defects in Stargardt-like Maculopathy (STGD3). Sci. Rep. UK 2018, 8, 5944. [CrossRef]

17. Aldahmesh, M.A.; Mohamed, J.Y.; Alkuraya, H.S.; Verma, I.C.; Puri, R.D.; Alaiya, A.A.; Rizzo, W.B.; Alkuraya, F.S. Recessive Mutations in ELOVL4 Cause Ichthyosis, Intellectual Disability, and Spastic Quadriplegia. Am. J. Hum. Genet. 2011, 89, 745-750. [CrossRef]

18. Sompallae, R.; Hofmann, O.; Maher, C.A.; Gedye, C.; Behren, A.; Vitezic, M.; Daub, C.O.; Devalle, S.; Caballero, O.L.; Carninci, P.; et al. Comprehensive Promoter Landscape Identifies a Novel Promoter for CD133 in Restricted Tissues, Cancers, and Stem Cells. Front. Genet. 2013, 4, 209. [CrossRef] [PubMed]

19. Li, Z. CD133: A stem cell biomarker and beyond. Exp. Hematol. Oncol. 2013, 2, 17. [CrossRef]

20. Yang, Z.; Chen, Y.; Lillo, C.; Chien, J.; Yu, Z.; Michaelides, M.; Klein, M.; Howes, K.A.; Li, Y.; Kaminoh, Y.; et al. Mutant Prominin 1 Found in Patients with Macular Degeneration Disrupts Photoreceptor Disk Morphogenesis in Mice. J. Clin. Investig. 2008, 118, 2908-2916. [CrossRef]

21. Bhattacharya, S.; Yin, J.; Winborn, C.S.; Zhang, Q.; Yue, J.; Chaum, E. Prominin-1 Is a Novel Regulator of Autophagy in the Human Retinal Pigment EpitheliumProm1 Negatively Regulates mTOR Signaling. Investig. Ophthalmol. Vis. Sci. 2017, 58, $2366-2387$. [CrossRef] 
22. Permanyer, J.; Navarro, R.; Friedman, J.; Pomares, E.; Castro-Navarro, J.; Marfany, G.; Swaroop, A.; Gonzàlez-Duarte, R. Autosomal Recessive Retinitis Pigmentosa with Early Macular Affectation Caused by Premature Truncation in PROM1. Investig. Ophthalmol. Vis. Sci. 2010, 51, 2656-2663. [CrossRef] [PubMed]

23. Cehajic-Kapetanovic, J.; Birtel, J.; McClements, M.E.; Shanks, M.E.; Clouston, P.; Downes, S.M.; Issa, P.C.; MacLaren, R.E. Clinical and Molecular Characterization of PROM1-Related Retinal Degeneration. JAMA Netw. Open 2019, 2, e195752. [CrossRef]

24. Michaelides, M.; Gaillard, M.-C.; Escher, P.; Tiab, L.; Bedell, M.; Borruat, F.-X.; Barthelmes, D.; Carmona, R.; Zhang, K.; White, E.; et al. The PROM1 Mutation p.R373C Causes an Autosomal Dominant Bull's Eye Maculopathy Associated with Rod, Rod-Cone, and Macular Dystrophy. Investig. Ophthalmol. Vis. Sci. 2010, 51, 4771-4780. [CrossRef] [PubMed]

25. Radu, R.A.; Yuan, Q.; Hu, J.; Peng, J.H.; Lloyd, M.; Nusinowitz, S.; Bok, D.; Travis, G.H. Accelerated Accumulation of Lipofuscin Pigments in the RPE of a Mouse Model for ABCA4-Mediated Retinal Dystrophies Following Vitamin A Supplementation. Investig. Ophthalmol. Vis. Sci. 2008, 49, 3821-3829. [CrossRef] [PubMed]

26. Weng, J.; Mata, N.L.; Azarian, S.M.; Tzekov, R.T.; Birch, D.G.; Travis, G.H. Insights into the function of Rim protein in photoreceptors and etiology of Stargardt's disease from the phenotype in abcr knockout mice. Cell 1999, 98, 13-23. [CrossRef]

27. Sparrow, J.R.; Blonska, A.; Flynn, E.; Duncker, T.; Greenberg, J.P.; Secondi, R.; Ueda, K.; Delori, F.C. Quantitative Fundus Autofluorescence in Mice: Correlation with HPLC Quantitation of RPE Lipofuscin and Measurement of Retina Outer Nuclear Layer Thickness. Investig. Ophthalmol. Vis. Sci. 2013, 54, 2812-2820. [CrossRef] [PubMed]

28. Issa, P.C.; Barnard, A.R.; Singh, M.S.; Carter, E.; Jiang, Z.; Radu, R.A.; Schraermeyer, U.; MacLaren, R.E. Fundus Autofluorescence in the $\mathrm{Abca}^{-/-}$Mouse Model of Stargardt Disease-Correlation with Accumulation of A2E, Retinal Function and Histology. Investig. Ophthalmol. Vis. Sci. 2013. [CrossRef]

29. Zhang, N.; Tsybovsky, Y.; Kolesnikov, A.V.; Rozanowska, M.; Swider, M.; Schwartz, S.B.; Stone, E.M.; Palczewska, G.; Maeda, A.; Kefalov, V.J.; et al. Protein Misfolding and the Pathogenesis of ABCA4-Associated Retinal Degenerations. Hum. Mol. Genet. 2015, 24, 3220-3237. [CrossRef]

30. Molday, L.L.; Wahl, D.; Sarunic, M.V.; Molday, R.S. Localization and functional characterization of the p.Asn965Ser (N965S) $A B C A 4$ variant in mice reveal pathogenic mechanisms underlying Stargardt macular degeneration. Hum. Mol. Genet. 2017, 27, 295-306. [CrossRef]

31. Raz-Prag, D.; Ayyagari, R.; Fariss, R.N.; Mandal, M.N.A.; Vasireddy, V.; Majchrzak, S.; Webber, A.L.; Bush, R.A.; Salem, N.; Petrukhin, K.; et al. Haploinsufficiency Is Not the Key Mechanism of Pathogenesis in a Heterozygous Elovl4 Knockout Mouse Model of STGD3 Disease. Investig. Ophthalmol. Vis. Sci. 2006, 47, 3603-3611. [CrossRef] [PubMed]

32. Li, W.; Chen, Y.; Cameron, D.J.; Wang, C.; Karan, G.; Yang, Z.; Zhao, Y.; Pearson, E.; Chen, H.; Deng, C.; et al. Elovl4 Haploinsufficiency Does Not Induce Early Onset Retinal Degeneration in Mice. Vis. Res. 2007, 47, 714-722. [CrossRef] [PubMed]

33. McMahon, A.; Jackson, S.N.; Woods, A.S.; Kedzierski, W. A Stargardt disease-3 mutation in the mouse Elovl4 gene causes retinal deficiency of C32-C36 acyl phosphatidylcholines. FEBS Lett. 2007, 581, 5459-5463. [CrossRef]

34. Vasireddy, V.; Jablonski, M.M.; Khan, N.W.; Wang, X.F.; Sahu, P.; Sparrow, J.R.; Ayyagari, R. Elovl4 5-Bp Deletion Knock-in Mouse Model for Stargardt-like Macular Degeneration Demonstrates Accumulation of ELOVL4 and Lipofuscin. Exp. Eye Res. 2009, 89, 905-912. [CrossRef]

35. Karan, G.; Lillo, C.; Yang, Z.; Cameron, D.J.; Locke, K.G.; Zhao, Y.; Thirumalaichary, S.; Li, C.; Birch, D.G.; Vollmer-Snarr, H.R.; et al. Lipofuscin Accumulation, Abnormal Electrophysiology, and Photoreceptor Degeneration in Mutant ELOVL4 Transgenic Mice: A Model for Macular Degeneration. Proc. Natl. Acad. Sci. USA 2005, 102, 4164-4169. [CrossRef] [PubMed]

36. Hopiavuori, B.R.; Anderson, R.E.; Agbaga, M.-P. ELOVL4: Very long-chain fatty acids serve an eclectic role in mammalian health and function. Prog. Retin. Eye Res. 2019, 69, 137-158. [CrossRef] [PubMed]

37. Dellett, M.; Sasai, N.; Nishide, K.; Becker, S.; Papadaki, V.; Limb, G.A.; Moore, A.T.; Kondo, T.; Ohnuma, S.-I. Genetic Background and Light-Dependent Progression of Photoreceptor Cell Degeneration in Prominin-1 Knockout Mice. Investig. Ophthalmol. Vis. Sci. 2014, 56, 164-176. [CrossRef] [PubMed]

38. Garces, F.; Jiang, K.; Molday, L.L.; Stöhr, H.; Weber, B.H.; Lyons, C.J.; Maberley, D.; Molday, R.S. Correlating the Expression and Functional Activity of $A B C A 4$ Disease Variants with the Phenotype of Patients With Stargardt Disease. Investig. Ophthalmol. Vis. Sci. 2018, 59, 2305-2315. [CrossRef] [PubMed]

39. Sangermano, R.; Khan, M.; Cornelis, S.S.; Richelle, V.; Albert, S.; Garanto, A.; Elmelik, D.; Qamar, R.; Lugtenberg, D.; van den Born, L.I.; et al. ABCA4 Midigenes Reveal the Full Splice Spectrum of All Reported Noncanonical Splice Site Variants in Stargardt Disease. Genome Res. 2018, 28, 100-110. [CrossRef]

40. Claassen, J.N.; Zhang, D.; Chen, S.-C.; Moon, S.Y.; Lamey, T.; Thompson, J.A.; McLaren, T.; Roach, J.N.D.; McLenachan, S.; Chen, F.K. Generation of the Induced Pluripotent Stem Cell Line from a Patient with Autosomal Recessive ABCA4-Mediated Stargardt Macular Dystrophy. Stem Cell Res. 2018, 34, 101352. [CrossRef]

41. Ścieżyńska, A.; Soszyńska, M.; Komorowski, M.; Podgórska, A.; Krześniak, N.; Nogowska, A.; Smolińska, M.; Szulborski, K.; Szaflik, J.P.; Noszczyk, B.; et al. Molecular Analysis of the ABCA4 Gene Mutations in Patients with Stargardt Disease Using Human Hair Follicles. Int. J. Mol. Sci. 2020, 21, 3430. [CrossRef]

42. Lane, A.; Jovanovic, K.; Shortall, C.; Ottaviani, D.; Panes, A.B.; Schwarz, N.; Guarascio, R.; Hayes, M.J.; Palfi, A.; Chadderton, N.; et al. Modeling and Rescue of RP2 Retinitis Pigmentosa Using IPSC-Derived Retinal Organoids. Stem Cell Rep. 2020, 15, 67-79. [CrossRef] 
43. Kallman, A.; Capowski, E.E.; Wang, J.; Kaushik, A.M.; Jansen, A.D.; Edwards, K.L.; Chen, L.; Berlinicke, C.A.; Phillips, M.J.; Pierce, E.A.; et al. Investigating Cone Photoreceptor Development Using Patient-Derived NRL Null Retinal Organoids. Commun. Biol. 2020, 3, 82. [CrossRef] [PubMed]

44. Gao, M.-L.; Lei, X.-L.; Han, F.; He, K.-W.; Jin, S.-Q.; Zhang, Y.-Y.; Jin, Z.-B. Patient-Specific Retinal Organoids Recapitulate Disease Features of Late-Onset Retinitis Pigmentosa. Front. Cell Dev. Biol. 2020, 8, 128. [CrossRef]

45. Deng, W.-L.; Gao, M.-L.; Lei, X.-L.; Lv, J.-N.; Zhao, H.; He, K.-W.; Xia, X.-X.; Li, L.-Y.; Chen, Y.-C.; Li, Y.-P.; et al. Gene Correction Reverses Ciliopathy and Photoreceptor Loss in IPSC-Derived Retinal Organoids from Retinitis Pigmentosa Patients. Stem Cell Rep. 2018, 10, 1267-1281. [CrossRef] [PubMed]

46. Huang, K.-C.; Wang, M.-L.; Chen, S.-J.; Kuo, J.-C.; Wang, W.-J.; Nguyen, P.N.N.; Wahlin, K.J.; Lu, J.-F.; Tran, A.A.; Shi, M.; et al. Morphological and Molecular Defects in Human Three-Dimensional Retinal Organoid Model of X-Linked Juvenile Retinoschisis. Stem Cell Rep. 2019, 13, 906-923. [CrossRef] [PubMed]

47. Buskin, A.; Zhu, L.; Chichagova, V.; Basu, B.; Mozaffari-Jovin, S.; Dolan, D.; Droop, A.; Collin, J.; Bronstein, R.; Mehrotra, S.; et al. Disrupted Alternative Splicing for Genes Implicated in Splicing and Ciliogenesis Causes PRPF31 Retinitis Pigmentosa. Nat. Commun. 2018, 9, 4234. [CrossRef] [PubMed]

48. Kruczek, K.; Qu, Z.; Gentry, J.; Fadl, B.R.; Gieser, L.; Hiriyanna, S.; Batz, Z.; Samant, M.; Samanta, A.; Chu, C.J.; et al. Gene Therapy of Dominant CRX-Leber Congenital Amaurosis Using Patient Stem Cell-Derived Retinal Organoids. Stem Cell Rep. 2021, 16, 252-263. [CrossRef]

49. Cuevas, E.; Holder, D.L.; Alshehri, A.H.; Tréguier, J.; Lakowski, J.; Sowden, J.C. NRL- / - gene edited human embryonic stem cells generate rod-deficient retinal organoids enriched in S-cone-like photoreceptors. Stem Cells 2021, 39, 414-428. [CrossRef] [PubMed]

50. Russell, S.; Bennett, J.; Wellman, J.A.; Chung, D.C.; Yu, Z.-F.; Tillman, A.; Wittes, J.; Pappas, J.; Elci, O.; McCague, S.; et al. Efficacy and Safety of Voretigene Neparvovec (AAV2-HRPE65v2) in Patients with RPE65-Mediated Inherited Retinal Dystrophy: A Randomised, Controlled, Open-Label, Phase 3 Trial. Lancet 2017, 390, 849-860. [CrossRef]

51. Xue, K.; Jolly, J.K.; Barnard, A.R.; Rudenko, A.; Salvetti, A.P.; Patrício, M.I.; Edwards, T.L.; Groppe, M.; Orlans, H.O.; Tolmachova, T.; et al. Beneficial Effects on Vision in Patients Undergoing Retinal Gene Therapy for Choroideremia. Nat. Med. 2018, 24, 1507-1512. [CrossRef] [PubMed]

52. Cehajic-Kapetanovic, J.; Xue, K.; de la Camara, C.M.-F.; Nanda, A.; Davies, A.; Wood, L.J.; Salvetti, A.P.; Fischer, M.D.; Aylward, J.W.; Barnard, A.R.; et al. Initial Results from a First-in-Human Gene Therapy Trial on X-Linked Retinitis Pigmentosa Caused by Mutations in RPGR. Nat. Med. 2020, 26, 354-359. [CrossRef] [PubMed]

53. Grieger, J.C.; Samulski, R.J. Packaging capacity of adeno-associated virus serotypes: Impact of larger genomes on infectivity and postentry steps. J. Virol. 2005, 79, 9933-9944. [CrossRef]

54. Balaggan, K.S.; Binley, K.; Esapa, M.; Iqball, S.; Askham, Z.; Kan, O.; Tschernutter, M.; Bainbridge, J.W.B.; Naylor, S.; Ali, R.R. Stable and Efficient Intraocular Gene Transfer Using Pseudotyped EIAV Lentiviral Vectors. J. Gene Med. 2006, 8, 275-285. [CrossRef]

55. Binley, K.; Widdowson, P.; Loader, J.; Kelleher, M.; Iqball, S.; Ferrige, G.; de Belin, J.; Carlucci, M.; Angell-Manning, D.; Hurst, F.; et al. Transduction of Photoreceptors with EIAV Lentiviral Vectors; Safety and Biodistribution of StarGenTM for Stargardt Disease. Investig. Ophthalmol. Vis. Sci. 2013. [CrossRef] [PubMed]

56. Kong, J.; Kim, S.-R.; Binley, K.; Pata, I.; Doi, K.; Mannik, J.; Zernant-Rajang, J.; Kan, O.; Iqball, S.; Naylor, S.; et al. Correction of the Disease Phenotype in the Mouse Model of Stargardt Disease by Lentiviral Gene Therapy. Gene Ther. 2008, 15, 1311-1320. [CrossRef] [PubMed]

57. Burgoyne, T.; Meschede, I.P.; Burden, J.J.; Bailly, M.; Seabra, M.C.; Futter, C.E. Rod disc renewal occurs by evagination of the ciliary plasma membrane that makes cadherin-based contacts with the inner segment. Proc. Natl. Acad. Sci. USA 2015, 112, 15922-15927. [CrossRef]

58. Puppo, A.; Cesi, G.; Marrocco, E.; Piccolo, P.; Jacca, S.; Shayakhmetov, D.M.; Parks, R.J.; Davidson, B.L.; Colloca, S.; Brunetti-Pierri, N.; et al. Retinal Transduction Profiles by High-Capacity Viral Vectors. Gene Ther. 2014. [CrossRef] [PubMed]

59. Nuzbrokh, Y.; Kassotis, A.S.; Ragi, S.D.; Jauregui, R.; Tsang, S.H. Treatment-Emergent Adverse Events in Gene Therapy Trials for Inherited Retinal Diseases: A Narrative Review. Ophthalmol. Ther. 2020, 36, 1-16. [CrossRef] [PubMed]

60. Allocca, M.; Doria, M.; Petrillo, M.; Colella, P.; Garcia-Hoyos, M.; Gibbs, D.; Kim, S.R.; Maguire, A.; Rex, T.S.; Vicino, U.D.; et al. Serotype-Dependent Packaging of Large Genes in Adeno-Associated Viral Vectors Results in Effective Gene Delivery in Mice. J. Clin. Investig. 2008, 118, 1955-1964. [CrossRef]

61. Dong, B.; Nakai, H.; Xiao, W. Characterization of Genome Integrity for Oversized Recombinant AAV Vector. Mol. Ther. J. Am. Soc. Gene Ther. 2010, 18, 87-92. [CrossRef]

62. Wu, Z.; Yang, H.; Colosi, P. Effect of genome size on AAV vector packaging. Mol. Ther. J. Am. Soc. Gene Ther. 2010, 18, 80-86. [CrossRef] [PubMed]

63. Lai, Y.; Yue, Y.; Duan, D. Evidence for the failure of adeno-associated virus serotype 5 to package a viral genome $>$ or $=8.2 \mathrm{~kb}$. Mol. Ther. J. Am. Soc. Gene Ther. 2010, 18, 75-79. [CrossRef]

64. McClements, M.E.; MacLaren, R.E. Adeno-associated Virus (AAV) Dual Vector Strategies for Gene Therapy Encoding Large Transgenes. Yale J. Biol. Med. 2016, 90, 611-623. [CrossRef] 
65. McClements, M.E.; Issa, P.C.; Blouin, V.; MacLaren, R.E. A fragmented adeno-associated viral dual vector strategy for treatment of diseases caused by mutations in large genes leads to expression of hybrid transcripts. J. Genet. Syndr. Gene Ther. $2016,7,311$. [CrossRef] [PubMed]

66. Tornabene, P.; Trapani, I. Can Adeno-Associated Viral Vectors Deliver Effectively Large Genes? Hum. Gene Ther. 2020, 31, 47-56. [CrossRef] [PubMed]

67. Trapani, I.; Colella, P.; Sommella, A.; Iodice, C.; Cesi, G.; de Simone, S.; Marrocco, E.; Rossi, S.; Giunti, M.; Palfi, A.; et al. Effective Delivery of Large Genes to the Retina by Dual AAV Vectors. EMBO Mol. Med. 2014, 6, 194-211. [CrossRef] [PubMed]

68. McClements, M.E.; Barnard, A.R.; Singh, M.S.; Issa, P.C.; Jiang, Z.; Radu, R.A.; MacLaren, R.E. An AAV Dual Vector Strategy Ameliorates the Stargardt Phenotype in Adult Abca4-/- Mice. Hum. Gene Ther. 2018, 30, 590-600. [CrossRef]

69. Yang, J.; Zhou, W.; Zhang, Y.; Zidon, T.; Ritchie, T.; Engelhardt, J.F. Concatamerization of adeno-associated virus circular genomes occurs through intermolecular recombination. J. Virol. 1999, 73, 9468-9477. [CrossRef] [PubMed]

70. Reich, S.J.; Auricchio, A.; Hildinger, M.; Glover, E.; Maguire, A.M.; Wilson, J.M.; Bennett, J. Efficient Trans-Splicing in the Retina Expands the Utility of Adeno-Associated Virus as a Vector for Gene Therapy. Hum. Gene Ther. 2003, 14, 37-44. [CrossRef] [PubMed]

71. Colella, P.; Trapani, I.; Cesi, G.; Sommella, A.; Manfredi, A.; Puppo, A.; Iodice, C.; Rossi, S.; Simonelli, F.; Giunti, M.; et al. Efficient Gene Delivery to the Cone-Enriched Pig Retina by Dual AAV Vectors. Gene Ther. 2014, 21, 450-456. [CrossRef] [PubMed]

72. Schnepp, B.C.; Jensen, R.L.; Chen, C.-L.; Johnson, P.R.; Clark, K.R. Characterization of adeno-associated virus genomes isolated from human tissues. J. Virol. 2005, 79, 14793-14803. [CrossRef] [PubMed]

73. Straus, S.E.; Sebring, E.D.; Rose, J.A. Concatemers of alternating plus and minus strands are intermediates in adenovirusassociated virus DNA synthesis. Proc. Natl. Acad. Sci. USA 1976, 73, 742-746. [CrossRef]

74. Duan, D.; Yan, Z.; Yue, Y.; Engelhardt, J.F. Structural analysis of adeno-associated virus transduction circular intermediates. Virology 1999, 261, 8-14. [CrossRef] [PubMed]

75. Ghosh, A.; Yue, Y.; Lai, Y.; Duan, D. A hybrid vector system expands adeno-associated viral vector packaging capacity in a transgene-independent manner. Mol. Ther. J. Am. Soc. Gene Ther. 2008, 16, 124-130. [CrossRef]

76. Ghosh, A.; Yue, Y.; Duan, D. Efficient transgene reconstitution with hybrid dual AAV vectors carrying the minimized bridging sequences. Hum. Gene Ther. 2011, 22, 77-83. [CrossRef] [PubMed]

77. Trapani, I.; Toriello, E.; de Simone, S.; Colella, P.; Iodice, C.; Polishchuk, E.V.; Sommella, A.; Colecchi, L.; Rossi, S.; Simonelli, F.; et al. Improved dual AAV vectors with reduced expression of truncated proteins are safe and effective in the retina of a mouse model of Stargardt disease. Hum. Mol. Genet. 2015, 24, 6811-6825. [CrossRef]

78. Dyka, F.M.; Molday, L.L.; Chiodo, V.A.; Molday, R.S.; Hauswirth, W.W. Dual ABCA4-AAV Vector Treatment Reduces Pathogenic Retinal A2E Accumulation in a Mouse Model of Autosomal Recessive Stargardt Disease. Hum. Gene Ther. 2019, 30, 1361-1370. [CrossRef]

79. Tornabene, P.; Trapani, I.; Minopoli, R.; Centrulo, M.; Lupo, M.; de Simone, S.; Tiberi, P.; Dell'Aquila, F.; Marrocco, E.; Iodice, C.; et al. Intein-Mediated Protein Trans-Splicing Expands Adeno-Associated Virus Transfer Capacity in the Retina. Sci. Transl. Med. 2019, 11, eaav4523. [CrossRef] [PubMed]

80. Dyka, F.M.; Boye, S.L.; Chiodo, V.A.; Hauswirth, W.W.; Boye, S.E. Dual adeno-associated virus vectors result in efficient in vitro and in vivo expression of an oversized gene, MYO7A. Hum. Gene Ther. Methods 2014, 25, 166-177. [CrossRef]

81. Li, J.; Sun, W.; Wang, B.; Xiao, X.; Liu, X.-Q. Protein trans-splicing as a means for viral vector-mediated in vivo gene therapy. Hum. Gene Ther. 2008, 19, 958-964. [CrossRef] [PubMed]

82. McClements, M.E.; Barnard, A.R.; Issa, P.C.; MacLaren, R.E. Assessment of AAV Dual Vector Safety in the Abca4 ${ }^{-/-}$Mouse Model of Stargardt Disease. Transl. Vis. Sci. Technol. 2020, 9, 20. [CrossRef] [PubMed]

83. Bucher, K.; Rodríguez-Bocanegra, E.; Dauletbekov, D.; Fischer, M.D. Immune responses to retinal gene therapy using adenoassociated viral vectors-Implications for treatment success and safety. Prog. Retin. Eye Res. 2020, 100915. [CrossRef]

84. Chandler, L.C.; McClements, M.E.; Yusuf, I.H.; de la Camara, C.M.-F.; MacLaren, R.E.; Xue, K. Characterizing the Cellular Immune Response to Subretinal AAV Gene Therapy in the Murine Retina. Mol. Ther. Methods Clin. Dev. 2021. [CrossRef]

85. Han, Z.; Conley, S.M.; Makkia, R.S.; Cooper, M.J.; Naash, M.I. DNA nanoparticle-mediated ABCA4 delivery rescues Stargardt dystrophy in mice. J. Clin. Investig. 2012, 122, 3221-3226. [CrossRef] [PubMed]

86. Sun, D.; Schur, R.M.; Sears, A.E.; Gao, S.-Q.; Vaidya, A.; Sun, W.; Maeda, A.; Kern, T.; Palczewski, K.; Lu, Z.-R. Non-Viral Gene Therapy for Stargardt Disease with ECO/PRHO-ABCA4 Self-Assembled Nanoparticles. Mol. Ther. 2020, 28, 293-303. [CrossRef]

87. Sun, D.; Maeno, H.; Gujrati, M.; Schur, R.; Maeda, A.; Maeda, T.; Palczewski, K.; Lu, Z. Self-Assembly of a Multifunctional Lipid With Core-Shell Dendrimer DNA Nanoparticles Enhanced Efficient Gene Delivery at Low Charge Ratios into RPE Cells. Macromol. Biosci. 2015, 15, 1663-1672. [CrossRef] [PubMed]

88. Gujrati, M.; Malamas, A.; Shin, T.; Jin, E.; Sun, Y.; Lu, Z.-R. Multifunctional Cationic Lipid-Based Nanoparticles Facilitate Endosomal Escape and Reduction-Triggered Cytosolic siRNA Release. Mol. Pharmaceut. 2014, 11, 2734-2744. [CrossRef]

89. Sun, D.; Sun, W.; Gao, S.-Q.; Wei, C.; Naderi, A.; Schilb, A.L.; Scheidt, J.; Lee, S.; Kern, T.S.; Palczewski, K.; et al. Formulation and Efficacy of ECO/PRHO-ABCA4-SV40 Nanoparticles for Nonviral Gene Therapy of Stargardt Disease in a Mouse Model. J. Control. Release 2021, 330, 329-340. [CrossRef]

90. Xue, K.; MacLaren, R.E. Antisense oligonucleotide therapeutics in clinical trials for the treatment of inherited retinal diseases. Expert Opin. Investig. Drugs 2020, 29, 1163-1170. [CrossRef] 
91. Tomkiewicz, T.Z.; Suárez-Herrera, N.; Cremers, F.P.M.; Collin, R.W.J.; Garanto, A. Antisense Oligonucleotide-Based Rescue of Aberrant Splicing Defects Caused by 15 Pathogenic Variants in ABCA4. Int. J. Mol. Sci. 2021, 22, 4621. [CrossRef] [PubMed]

92. Cideciyan, A.V.; Jacobson, S.G.; Drack, A.V.; Ho, A.C.; Charng, J.; Garafalo, A.V.; Roman, A.J.; Sumaroka, A.; Han, I.C.; Hochstedler, M.D.; et al. Effect of an Intravitreal Antisense Oligonucleotide on Vision in Leber Congenital Amaurosis Due to a Photoreceptor Cilium Defect. Nat. Med. 2018, 25, 225-228. [CrossRef]

93. Cideciyan, A.V.; Jacobson, S.G.; Ho, A.C.; Garafalo, A.V.; Roman, A.J.; Sumaroka, A.; Krishnan, A.K.; Swider, M.; Schwartz, M.R.; Girach, A. Durable Vision Improvement after a Single Treatment with Antisense Oligonucleotide Sepofarsen: A Case Report. Nat. Med. 2021, 27, 785-789. [CrossRef]

94. Deák, F.; Anderson, R.E.; Fessler, J.L.; Sherry, D.M. Novel Cellular Functions of Very Long Chain-Fatty Acids: Insight from ELOVL4 Mutations. Front. Cell. Neurosci. 2019, 13, 428. [CrossRef] [PubMed]

95. Mayer, A.K.; Rohrschneider, K.; Strom, T.M.; Glöckle, N.; Kohl, S.; Wissinger, B.; Weisschuh, N. Homozygosity Mapping and Whole-Genome Sequencing Reveals a Deep Intronic PROM1 Mutation Causing Cone-Rod Dystrophy by Pseudoexon Activation. Eur. J. Hum. Genet. 2016, 24, 459-462. [CrossRef] [PubMed]

96. Albert, S.; Garanto, A.; Sangermano, R.; Khan, M.; Bax, N.M.; Hoyng, C.B.; Zernant, J.; Lee, W.; Allikmets, R.; Collin, R.W.J.; et al. Identification and Rescue of Splice Defects Caused by Two Neighboring Deep-Intronic ABCA4 Mutations Underlying Stargardt Disease. Am. J. Hum. Genet. 2018, 102, 517-527. [CrossRef] [PubMed]

97. Garanto, A.; Duijkers, L.; Tomkiewicz, T.Z.; Collin, R.W.J. Antisense Oligonucleotide Screening to Optimize the Rescue of the Splicing Defect Caused by the Recurrent Deep-Intronic ABCA4 Variant c.4539+2001G>A in Stargardt Disease. Genes 2019, 10, 452. [CrossRef]

98. Khan, M.; Arno, G.; Fakin, A.; Parfitt, D.A.; Dhooge, P.P.A.; Albert, S.; Bax, N.M.; Duijkers, L.; Niblock, M.; Hau, K.L.; et al. Detailed Phenotyping and Therapeutic Strategies for Intronic ABCA4 Variants in Stargardt Disease. Mol. Ther. Nucleic Acids 2020, 21, 412-427. [CrossRef]

99. Garanto, A.; Chung, D.C.; Duijkers, L.; Corral-Serrano, J.C.; Messchaert, M.; Xiao, R.; Bennett, J.; Vandenberghe, L.H.; Collin, R.W.J. In Vitro and in Vivo Rescue of Aberrant Splicing in CEP290 -Associated LCA by Antisense Oligonucleotide Delivery. Hum. Mol. Genet. 2016, 25, 2552-2563. [CrossRef] [PubMed]

100. Merkle, T.; Merz, S.; Reautschnig, P.; Blaha, A.; Li, Q.; Vogel, P.; Wettengel, J.; Li, J.B.; Stafforst, T. Precise RNA Editing by Recruiting Endogenous ADARs with Antisense Oligonucleotides. Nat. Biotechnol. 2019, 37, 133-138. [CrossRef]

101. George, C.X.; Samuel, C.E. Human RNA-specific adenosine deaminase ADAR1 transcripts possess alternative exon 1 structures that initiate from different promoters, one constitutively active and the other interferon inducible. Proc. Natl. Acad. Sci. USA 1999, 96, 4621-4626. [CrossRef] [PubMed]

102. Maas, S.; Gommans, W.M. Identification of a selective nuclear import signal in adenosine deaminases acting on RNA. Nucleic Acids Res. 2009, 37, 5822-5829. [CrossRef]

103. Wang, A.L.; Carroll, R.C.; Nawy, S. Down-Regulation of the RNA Editing Enzyme ADAR2 Contributes to RGC Death in a Mouse Model of Glaucoma. PLoS ONE 2014, 9, e91288. [CrossRef]

104. Qu, L.; Yi, Z.; Zhu, S.; Wang, C.; Cao, Z.; Zhou, Z.; Yuan, P.; Yu, Y.; Tian, F.; Liu, Z.; et al. Programmable RNA Editing by Recruiting Endogenous ADAR Using Engineered RNAs. Nat. Biotechnol. 2019, 37, 1059-1069. [CrossRef]

105. Katrekar, D.; Chen, G.; Meluzzi, D.; Ganesh, A.; Worlikar, A.; Shih, Y.-R.; Varghese, S.; Mali, P. In Vivo RNA Editing of Point Mutations via RNA-Guided Adenosine Deaminases. Nat. Methods 2019, 16, 239-242. [CrossRef] [PubMed]

106. Fry, L.E.; Peddle, C.F.; Barnard, A.R.; McClements, M.E.; MacLaren, R.E. RNA Editing as a Therapeutic Approach for Retinal Gene Therapy Requiring Long Coding Sequences. Int. J. Mol. Sci. 2020, 21, 777. [CrossRef]

107. Maeda, A.; Golczak, M.; Maeda, T.; Palczewski, K. Limited roles of Rdh8, Rdh12, and Abca4 in all-trans-retinal clearance in mouse retina. Investig. Ophthalmol. Vis. Sci. 2009, 50, 5435-5443. [CrossRef]

108. Kubota, R.; Al-Fayoumi, S.; Mallikaarjun, S.; Patil, S.; Bavik, C.; Chandler, J.W. Phase 1, dose-ranging study of emixustat hydrochloride (ACU-4429), a novel visual cycle modulator, in healthy volunteers. Retina 2014, 34, 603-609. [CrossRef]

109. Zhang, J.; Kiser, P.D.; Badiee, M.; Palczewska, G.; Dong, Z.; Golczak, M.; Tochtrop, G.P.; Palczewski, K. Molecular Pharmacodynamics of Emixustat in Protection against Retinal Degeneration. J. Clin. Investig. 2015, 125, 2781-2794. [CrossRef] [PubMed]

110. Kubota, R.; Birch, D.G.; Gregory, J.K.; Koester, J.M. Randomised study evaluating the pharmacodynamics of emixustat hydrochloride in subjects with macular atrophy secondary to Stargardt disease. Brit. J. Ophthalmol. 2020, 1-6. [CrossRef]

111. Zhou, J.; Jang, Y.P.; Kim, S.R.; Sparrow, J.R. Complement activation by photooxidation products of A2E, a lipofuscin constituent of the retinal pigment epithelium. Proc. Natl. Acad. Sci. USA 2006, 103, 16182-16187. [CrossRef] [PubMed]

112. Radu, R.A.; Hu, J.; Yuan, Q.; Welch, D.L.; Makshanoff, J.; Lloyd, M.; McMullen, S.; Travis, G.H.; Bok, D. Complement System Dysregulation and Inflammation in the Retinal Pigment Epithelium of a Mouse Model for Stargardt Macular Degeneration. J. Biol. Chem. 2011, 286, 18593-18601. [CrossRef]

113. Armento, A.; Ueffing, M.; Clark, S.J. The complement system in age-related macular degeneration. Cell. Mol. Life Sci. 2021, 1-19. [CrossRef]

114. Jaffe, G.J.; Westby, K.; Csaky, K.G.; Monés, J.; Pearlman, J.A.; Patel, S.S.; Joondeph, B.C.; Randolph, J.; Masonson, H.; Rezaei, K.A. C5 Inhibitor Avacincaptad Pegol for Geographic Atrophy Due to Age-Related Macular Degeneration A Randomized Pivotal Phase 2/3 Trial. Ophthalmology 2021, 128, 576-586. [CrossRef] [PubMed] 
115. Yehoshua, Z.; de Amorim Garcia Filho, C.A.; Nunes, R.P.; Gregori, G.; Penha, F.M.; Moshfeghi, A.A.; Zhang, K.; Sadda, S.; Feuer, W.; Rosenfeld, P.J. Systemic Complement Inhibition with Eculizumab for Geographic Atrophy in Age-Related Macular Degeneration the COMPLETE Study. Ophthalmology 2014, 121, 693-701. [CrossRef]

116. Kaufman, Y.; Ma, L.; Washington, I. Deuterium Enrichment of Vitamin A at the C20 Position Slows the Formation of Detrimental Vitamin A Dimers in Wild-type Rodents. J. Biol. Chem. 2011, 286, 7958-7965. [CrossRef] [PubMed]

117. Issa, P.C.; Barnard, A.R.; Herrmann, P.; Washington, I.; MacLaren, R.E. Rescue of the Stargardt phenotype in Abca4 knockout mice through inhibition of vitamin A dimerization. Proc. Natl. Acad. Sci. USA 2015, 112, 8415-8420. [CrossRef] [PubMed]

118. Scholl, H.P.; Tsang, S.H.; Kay, C.N.; Conner, T.B.; Gorin, M.B.; Bernstain, P.S.; Lam, B.L.; Strecker, Z.; Zaremba, T.; DeBartolomeo, G.; et al. Stargardt disease ALK-001 phase 2 clinical trial: 12-month interim data. Investig. Ophthalmol. Vis. Sci. 2019, 60, 1336.

119. Radu, R.A.; Han, Y.; Bui, T.V.; Nusinowitz, S.; Bok, D.; Lichter, J.; Widder, K.; Travis, G.H.; Mata, N.L. Reductions in Serum Vitamin A Arrest Accumulation of Toxic Retinal Fluorophores: A Potential Therapy for Treatment of Lipofuscin-Based Retinal Diseases. Investig. Ophthalmol. Vis. Sci. 2005, 46, 4393-4401. [CrossRef]

120. Mata, N.L.; Lichter, J.B.; Vogel, R.; Han, Y.; Bui, T.V.; Singerman, L.J. Investigation of oral fenretinide for treatment of geographic atrophy in age-related macular degeneration. Retina 2013, 33, 498-507. [CrossRef] [PubMed]

121. Dobri, N.; Qin, Q.; Kong, J.; Yamamoto, K.; Liu, Z.; Moiseyev, G.; Ma, J.; Allikmets, R.; Sparrow, J.R.; Petrukhin, K. A1120, a Nonretinoid RBP4 Antagonist, Inhibits Formation of Cytotoxic Bisretinoids in the Animal Model of Enhanced Retinal LipofuscinogenesisA1120 in the Animal Model of Retinal Lipofuscinogenesis. Investig Ophthalmol. Vis. Sci. 2013, 54, 85-95. [CrossRef] [PubMed]

122. Neuringer, M. Infant vision and retinal function in studies of dietary long-chain polyunsaturated fatty acids: Methods, results, and implications. Am. J. Clin. Nutr. 2000, 71, 256S-267S. [CrossRef] [PubMed]

123. MacDonald, I.M.; Sieving, P.A. Investigation of the effect of dietary docosahexaenoic acid (DHA) supplementation on macular function in subjects with autosomal recessive Stargardt macular dystrophy. Ophthalmic Genet. 2018, 39, 477-486. [CrossRef] [PubMed]

124. Dornstauder, B.; Suh, M.; Kuny, S.; Gaillard, F.; MacDonald, I.M.; Clandinin, M.T.; Sauvé, Y. Dietary Docosahexaenoic Acid Supplementation Prevents Age-Related Functional Losses and A2E Accumulation in the RetinaDietary DHA Delays Retinal Degeneration. Investig. Ophthalmol. Vis. Sci. 2012, 53, 2256-2265. [CrossRef]

125. Piccardi, M.; Fadda, A.; Martelli, F.; Marangoni, D.; Magli, A.; Minnella, A.M.; Bertelli, M.; Marco, S.D.; Bisti, S.; Falsini, B. Antioxidant Saffron and Central Retinal Function in ABCA4-Related Stargardt Macular Dystrophy. Nutrients 2019, $11,2461$. [CrossRef] [PubMed]

126. D'Cruz, P.M.; Yasumura, D.; Weir, J.; Matthes, M.T.; Abderrahim, H.; LaVail, M.M.; Vollrath, D. Mutation of the Receptor Tyrosine Kinase Gene Mertk in the Retinal Dystrophic RCS Rat. Hum. Mol. Genet. 2000, 9, 645-651. [CrossRef]

127. Lu, B.; Malcuit, C.; Wang, S.; Girman, S.; Francis, P.; Lemieux, L.; Lanza, R.; Lund, R. Long-Term Safety and Function of RPE from Human Embryonic Stem Cells in Preclinical Models of Macular Degeneration. Stem Cells 2009, 27, 2126-2135. [CrossRef]

128. Schwartz, S.D.; Regillo, C.D.; Lam, B.L.; Eliott, D.; Rosenfeld, P.J.; Gregori, N.Z.; Hubschman, J.-P.; Davis, J.L.; Heilwell, G.; Spirn, M.; et al. Human Embryonic Stem Cell-Derived Retinal Pigment Epithelium in Patients with Age-Related Macular Degeneration and Stargardt's Macular Dystrophy: Follow-up of Two Open-Label Phase 1/2 Studies. Lancet 2015, 385, 509-516. [CrossRef]

129. Mehat, M.S.; Sundaram, V.; Ripamonti, C.; Robson, A.G.; Smith, A.J.; Borooah, S.; Robinson, M.; Rosenthal, A.N.; Innes, W.; Weleber, R.G.; et al. Transplantation of Human Embryonic Stem Cell-Derived Retinal Pigment Epithelial Cells in Macular Degeneration. Ophthalmology 2018, 125, 1765-1775. [CrossRef]

130. Weiss, J.N.; Levy, S. Stem Cell Ophthalmology Treatment Study (SCOTS): Bone Marrow-Derived Stem Cells in the Treatment of Stargardt Disease. Medicines 2021, 8, 10. [CrossRef]

131. Parmar, V.M.; Parmar, T.; Arai, E.; Perusek, L.; Maeda, A. A2E-associated cell death and inflammation in retinal pigmented epithelial cells from human induced pluripotent stem cells. Stem Cell Res. 2018, 27, 95-104. [CrossRef]

132. Lee, J.; Bayarsaikhan, D.; Bayarsaikhan, G.; Kim, J.-S.; Schwarzbach, E.; Lee, B. Recent advances in genome editing of stem cells for drug discovery and therapeutic application. Pharm. Ther. 2020, 209, 107501. [CrossRef]

133. Kantor, A.; McClements, M.E.; Peddle, C.F.; Fry, L.E.; Salman, A.; Cehajic-Kapetanovic, J.; Xue, K.; MacLaren, R.E. CRISPR Genome Engineering for Retinal Diseases. Prog. Mol. Biol. Transl. 2021. [CrossRef]

134. Peddle, C.F.; Fry, L.E.; McClements, M.E.; MacLaren, R.E. CRISPR Interference-Potential Application in Retinal Disease. Int. J. Mol. Sci. 2020, 21, 2329. [CrossRef]

135. Quinn, J.; Musa, A.; Kantor, A.; McClements, M.E.; Cehajic-Kapetanovic, J.; MacLaren, R.E.; Xue, K. Genome-Editing Strategies for Treating Human Retinal Degenerations. Hum. Gene Ther. 2020. [CrossRef]

136. Kantor, A.; McClements, M.E.; MacLaren, R.E. CRISPR-Cas9 DNA Base-Editing and Prime-Editing. Int. J. Mol. Sci. 2020, $21,6240$. [CrossRef]

137. First CRISPR therapy dosed. Nat. Biotechnol. 2020, 38, 382. [CrossRef] [PubMed]

138. Maeder, M.L.; Stefanidakis, M.; Wilson, C.J.; Baral, R.; Barrera, L.A.; Bounoutas, G.S.; Bumcrot, D.; Chao, H.; Ciulla, D.M.; DaSilva, J.A.; et al. Development of a Gene-Editing Approach to Restore Vision Loss in Leber Congenital Amaurosis Type 10. Nature medicine 2019, 25, 229-233. [CrossRef] [PubMed] 
139. Imani, S.; Cheng, J.; Shasaltaneh, M.D.; Wei, C.; Yang, L.; Fu, S.; Zou, H.; Khan, M.A.; Zhang, X.; Chen, H.; et al. Genetic Identification and Molecular Modeling Characterization Reveal a Novel PROM1 Mutation in Stargardt4-like Macular Dystrophy. Oncotarget 2017, 9, 122-141. [CrossRef] [PubMed]

140. Salles, M.V.; Motta, F.L.; da Silva, E.D.; Teixeira, P.V.L.; Costa, K.A.; Filippelli-Silva, R.; Martin, R.; Pesquero, J.B.; Sallum, J.M.F. PROM1 Gene Variations in Brazilian Patients with Macular Dystrophy. Ophthalmic Genet 2017, 38, 39-42. [CrossRef]

141. Jinek, M.; Chylinski, K.; Fonfara, I.; Hauer, M.; Doudna, J.A.; Charpentier, E. A programmable dual-RNA-guided DNA endonuclease in adaptive bacterial immunity. Science 2012, 337, 816-821. [CrossRef]

142. Hu, Z.; Wang, S.; Zhang, C.; Gao, N.; Li., M.; Wang, D.; Wang, D.; Liu, D.; Liu, H.; Ong, S.; et al. A compact Cas9 ortholog from Staphylococcus Auricularis (SauriCas9) expands the DNA targeting scope. PLoS Biol. 2020, 18, e3000686. [CrossRef]

143. Kleinstiver, B.P.; Prew, M.S.; Tsai, S.Q.; Nguyen, N.T.; Topkar, V.V.; Zheng, Z.; Joung, J.K. Broadening the Targeting Range of Staphylococcus Aureus CRISPR-Cas9 by Modifying PAM Recognition. Nat. Biotechnol. 2015, 33, 1293-1298. [CrossRef]

144. Suh, S.; Choi, E.H.; Leinonen, H.; Foik, A.T.; Newby, G.A.; Yeh, W.-H.; Dong, Z.; Kiser, P.D.; Lyon, D.C.; Liu, D.R.; et al. Restoration of Visual Function in Adult Mice with an Inherited Retinal Disease via Adenine Base Editing. Nat. Biomed. Eng. 2020. [CrossRef] [PubMed]

145. McCullough, K.T.; Boye, S.L.; Fajardo, D.; Calabro, K.; Peterson, J.J.; Strang, C.E.; Chakraborty, D.; Gloskowski, S.; Haskett, S.; Samuelsson, S.; et al. Somatic Gene Editing of GUCY2D by AAV-CRISPR/Cas9 Alters Retinal Structure and Function in Mouse and Macaque. Hum. Gene Ther. 2019, 30, 571-589. [CrossRef] [PubMed]

146. Levy, J.M.; Yeh, W.-H.; Pendse, N.; Davis, J.R.; Hennessey, E.; Butcher, R.; Koblan, L.W.; Comander, J.; Liu, Q.; Liu, D.R. Cytosine and Adenine Base Editing of the Brain, Liver, Retina, Heart and Skeletal Muscle of Mice via Adeno-Associated Viruses. Nat. Biomed. Eng. 2020, 4, 97-110. [CrossRef]

147. Chung, S.H.; Mollhoff, I.N.; Nguyen, U.; Nguyen, A.; Stucka, N.; Tieu, E.; Manna, S.; Maleppat, R.K.; Zhang, P.; Nguyen, E.L.; et al. Factors Impacting Efficacy of AAV-Mediated CRISPR-Based Genome Editing for Treatment of Choroidal Neovascularization. Mol. Ther. Methods Clin. Dev. 2020, 17, 409-417. [CrossRef] [PubMed]

148. Lee, B.; Lee, K.; Panda, S.; Gonzales-Rojsa, R.; Chong, A.; Bugay, V.; Park, H.Y.; Brenner, R.; Murthy, N.; Lee, H.Y. Nanoparticle delivery of CRISPR into the brain rescues a mouse model of fragile $\mathrm{X}$ syndrome from exaggerated repetitive behaviours. Nat. Biomed. Eng. 2018, 2, 497-507. [CrossRef] [PubMed]

149. Müller, P.L.; Gliem, M.; Mangold, E.; Bolz, H.J.; Finger, R.P.; McGuinness, M.; Betz, C.; Jiang, Z.; Weber, B.H.F.; MacLaren, R.E.; et al. Monoallelic $A B C A 4$ Mutations Appear Insufficient to Cause Retinopathy: A Quantitative Autofluorescence Study. Investig. Ophthalmol. Vis. Sci. 2015, 56, 8179-8186. [CrossRef]

150. Jin, S.; Fei, H.; Zhu, Z.; Luo, Y.; Liu, J.; Gao, S.; Zhang, F.; Chen, Y.-H.; Wang, Y.; Gao, C. Rationally Designed APOBEC3B Cytosine Base Editors with Improved Specificity. Mol. Cell 2020, 79, 728-740. [CrossRef] [PubMed]

151. Anzalone, A.V.; Koblan, L.W.; Liu, D.R. Genome editing with CRISPR-Cas nucleases, base editors, transposases and prime editors. Nat. Biotechnol. 2020, 337, 1-21. [CrossRef]

152. Anzalone, A.V.; Randolph, P.B.; Davis, J.R.; Sousa, A.A.; Koblan, L.W.; Levy, J.M.; Chen, P.J.; Wilson, C.; Newby, G.A.; Raguram, A.; et al. Search-and-Replace Genome Editing without Double-Strand Breaks or Donor DNA. Nature 2019, 576, 149-157. [CrossRef] [PubMed]

153. Kweon, J.; Yoon, J.-K.; Jang, A.-H.; Shin, H.R.; See, J.-E.; Jang, G.; Kim, J.-I.; Kim, Y. Engineered Prime Editors with PAM Flexibility. Mol. Ther. 2021. [CrossRef] [PubMed] 